\title{
Pieces of eight, pieces of eight: seafarers' earnings and the venture economy of early modern seafaring
}

Article

Accepted Version

Blakemore, R. J. (2017) Pieces of eight, pieces of eight: seafarers' earnings and the venture economy of early modern seafaring. Economic History Review, 70 (4). pp. 1153-1184. ISSN 1468-0289 doi: https://doi.org/10.1111/ehr.12428 Available at https://centaur.reading.ac.uk/66967/

It is advisable to refer to the publisher's version if you intend to cite from the work. See Guidance on citing.

To link to this article DOI: http://dx.doi.org/10.1111/ehr.12428

Publisher: Wiley-Blackwell

All outputs in CentAUR are protected by Intellectual Property Rights law, including copyright law. Copyright and IPR is retained by the creators or other copyright holders. Terms and conditions for use of this material are defined in the End User Agreement.

$\underline{\text { www.reading.ac.uk/centaur }}$ 
Central Archive at the University of Reading

Reading's research outputs online 


\title{
Pieces of Eight, Pieces of Eight: Seafarers' Earnings and the Venture Economy of Early Modern Seafaring
}

\author{
Richard J. Blakemore
}

This is the peer reviewed version of the following article: Richard J. Blakemore, 'Pieces of Eight, Pieces of Eight: Seamen's Earnings and the Venture Economy of Early Modern Seafaring', which is forthcoming in The Economic History Review. This article may be used for non-commercial purposes in accordance with Wiley Terms and Conditions for SelfArchiving.

\begin{abstract}
Historians have generally argued that between the medieval period and the eighteenth century seafarers transformed from collaborative adventurers with a share in their vessel to the first international wage-earning proletariat. This interpretation has drawn upon relatively limited statistical analysis of mariners' wages, and underestimates the variety of seafarers' remuneration and economic activities besides wages themselves. This article undertakes a more sustained analysis of seventeenth-century wage data drawn from the papers of the English High Court of Admiralty, and uses the same evidence to examine other forms of income, both customary payments as part of shipping, and small-scale trade. Seafarers of all ranks carried their own commodities on all shipping routes, offering an opportunity to considerably increase their income. This evidence confirms that the maritime labour market was hierarchical, and that very often seafarers were poor labourers facing economic insecurity of many kinds. However, it refines the previous interpretation by emphasizing the presence of skilled workers even amongst the lower levels of this labour market, and by introducing a new dimension to mariners' economic agency: they were not simply wageworkers, but also independent participants in a venture economy.
\end{abstract}




\section{Pieces of Eight, Pieces of Eight: Seamen's Earnings and the Venture Economy of Early Modern Seafaring ${ }^{1}$}

In April 1642 the Fame of London set sail on a voyage to St Malo in northern France, and then 'to such other Ports and places as they could gett'. ${ }^{2}$ The voyage proved to be a long one: from St Malo the ship and its crew sailed to 'Aberdine' to load timber, which they carried to Cádiz. After a return trip taking corn to Tarragona in Valentia, they departed Cádiz for the Caribbean, then sailed back across the Atlantic to Sanlúcar, the last port before they turned north for home.

Aboard the Fame sailed sMichael Johnson. According to the depositions given by two of his shipmates in the High Court of Admiralty in London after the voyage, Johnson was an enterprising individual. He took with him 'an adventure [an investment in cash or goods]...of the value of aboute five or six pounds at the least'. The depositions do not mention Johnson's role and wages - his use of a 'Cabon' may indicate that he held a higher rank - but such an amount probably represented between three and six months' pay. This was a considerable sum to begin with, and as his friend Richard Wall told the court, 'with turneinge and winding of that adventure and with the wages he received abroade...Johnson did verye much increase' it.

Johnson bought 'wyne and linnen' in Spain which he carried to the Caribbean, and also 'lett out his Cabon to Spaniards that went passengers to and from the [West] Indies', earning 50 dollars on the way out and 60 on the way back (presumably Spanish dollars or pesos, famously known as 'pieces of eight'). ${ }^{3}$ At Veracruz, where he received eight months' wages, Johnson purchased two 'roves' of cochineal, which cost him somewhere around 300 pesos, and also 'two peeces of India silke stuffe' for about 50 pesos. ${ }^{4}$ When they visited Sanlúcar on the way home Johnson sold the cochineal, and bought some 'teal and a smale

\footnotetext{
${ }^{1}$ This article is based upon research conducted as part of the project 'Sailing into Modernity: Comparative Perspectives on the Sixteenth and Seventeenth Century European Transition', funded by the European Research Council (Starting Grant n. 284340). I am grateful to the ERC for their financial support; to the organisers and audiences of the Centre for Early Modern Studies Seminar, University of Exeter, and the Early Modern Discussion Group, University of Sheffield, where this material was presented; to my project colleagues Maria Fusaro, Bernard Allaire, and Tijl Vanneste; and to Simon Abernethy, Henry French, Colin Greenstreet, Colin Heywood, Edmond Smith, Brodie Waddell, and Jane Whittle.

${ }^{2}$ T[the] N[ational] A[rchives] HCA 13/59, depositions of Richard Wall and William Gare, 25 April 1645, fos 738r-40r. All quotations in the first three paragraphs are from these depositions.

${ }^{3}$ Pond, 'Spanish dollar'; McCusker, Money and exchange, p. 7.

${ }^{4}$ A 'rove' was approximately 25-36lb or 2.6-3.6 gallons; see Oxford English Dictionary, sub voce.
} 
parcell of fraight which did not...cost him verye much', leaving him with nearly 200 pesos 'in readye money'.

The anecdotal nature of the evidence does not permit a precise reckoning of Johnson's transactions, but even if they exaggerated in his favour his shipmates clearly felt he had done well, and we can pursue a rough calculation for the voyage. Historical currency exchange rates are notoriously difficult to recover, especially as Johnson presumably exchanged his money in various places throughout the voyage, but using the approximate rate of $£ 1=5$ pesos suggests that Johnson had nearly $£ 40$ in cash and $£ 10$ in 'silke stuffe' (valued at its purchase price) when he left Sanlúcar for England. ${ }^{5}$ Though conjectural, these sums - which do not include Johnson's remaining unpaid wages, or his unvalued goods - at least give an idea of how much he had accrued; certainly a larger sum than the 'adventure' of $£ 5$ or $£ 6$ with which he set out.

Here we have an unusually detailed vignette of a single seafarer's economic activities on one voyage, but it is enough to give us pause for thought. There is a generally accepted narrative which describes how seamen transformed, between the medieval and the modern period, from co-investors in maritime trade into the earliest example of an international wageearning proletariat, with far-reaching consequences for their social status and labour relations. ${ }^{6}$ Historians have explored the international nature of the maritime labour market in some detail, especially regarding migration and national identities; but we know rather less about seafarers' earnings, perhaps because the available evidence makes detailed analysis

\footnotetext{
${ }^{5}$ This is a conservative exchange rate, as McCusker, Money and exchange, pp. 99, 101-6, and Denzel, Handbook of world exchange rates, p. 30, give a London-Madrid rate fluctuating around $£ 1=4.5$ pesos for 1680-1725. Throughout the Mediterranean in the mid-seventeenth century, the rate was between $£ 1=5$ pesos and $£ 1=4$ pesos: see Blakemore, 'A descriptive report', pp. 12-14. Pesos were exchanged at different rates in the Caribbean, $£ 1=3$ pesos or even $£ 1=2$ pesos (McCusker, Money and exchange, pp. 118, 239, 346, 299300), which would affect the wages Johnson received there, but not their original value in sterling.

${ }^{6}$ Jackson, 'From profit-sailing to wage-sailing'; Unger, 'Regulation and organization of seamen'. The most forceful interpretation of seafarers as a 'proletariat' has been presented by Marcus Rediker, in Between the devil; Rediker, 'Common seaman'; Linebaugh and Rediker, The many-headed hydra. Some aspects of Redikers' approach have been criticised, e.g. in Armitage, 'The red Atlantic'; the roundtable reviews in the International Journal of Maritime History, 1 (1989), pp. 311-36, and 13 (2001), pp. 195-244; Davids, 'Seamen's organizations', p. 145-6; Lucassen, 'Multinational and its labour force', pp. 30-2; Bruijn, 'Seafarers in early modern and modern times', pp. 6-7; O’Hara, “"The sea is swinging into view”, pp. 1121-3; Van Lottum, Lucassen and Van Voss, 'Sailors, national and international labour markets', p. 349. However, Rediker's work remains influential: Dekker, 'Labour conflicts'; Pérez-Mallaina, Spain's men of the sea, pp. 191-7; Fumerton, Unsettled, pp. xx. 58, 65, 70-8, and ch. 6; Van der Linden, 'Labour history beyond borders', p. 371; Anderson, Frykman, Van Voss and Rediker, eds, 'Mutiny and maritime radicalism'.
} 
quite difficult. ${ }^{7}$ In consequence, seafarers are still widely regarded as poor wage labourers. The example of Michael Johnson 'turneinge and winding' his venture and pay into a (perhaps substantial) profit reveals the need to revisit this narrative, to consider seafarers' incomes both more precisely, in terms of the wages they received, and more broadly, including forms of non-wage remuneration.

I focus largely upon English merchant seamen, because of the richness of relevant material surviving from the High Court of Admiralty, and upon the late sixteenth and seventeenth centuries, when English shipping expanded rapidly in volume and activity. ${ }^{8}$ Section I offers a statistical analysis of English seafarers' wages based upon these sources. However, as Johnson's story shows, there were numerous opportunities within maritime commerce for seafarers to earn beyond the wages they were paid by shipmasters. Section II examines alternative wage-systems and forms of remuneration besides wages, while section III discusses the evidence for seafarers' participation in trade, demonstrating that Johnson was not an unusual entrepreneur but is representative of wider patterns in seafarers' economic agency.

Ralph Davis, the first historian to discuss maritime wages throughout the seventeenth and eighteenth centuries, set the tone for much of the discussion which followed. In a brief account of roughly estimated mean averages for monthly wages, based upon the admiralty court papers, he noted that mariners' wages were similar for different ports, rising from 17$18 \mathrm{~s}$. per month in the early seventeenth century to $24-25 \mathrm{~s}$. by the eighteenth, and fluctuating to much higher rates during wartime. ${ }^{9}$ Later scholars such as Kenneth Andrews and Peter

\footnotetext{
${ }^{7}$ Bruijn and Van Heslinga, 'Seamen's employment'; Lucassen, 'International maritime labour market'; Van Royen, 'The "national” maritime labour market'; Lucassen, 'Multinational and its labour force'; Bruijn, 'Seafarers in early modern and modern times'; Van Rossum, Van Voss, Van Lottum, and Lucassen, 'National and international labour markets'.

${ }^{8}$ Naval wages, generally lower than those in merchant ships, were set by the government; see Oppenheim, History of the administration, pp. 34, 41, 74-5, 113, 134, 152-3, 197, 225-6, 243-4, 314, 360.

${ }^{9}$ Davis, English shipping industry, pp. 135-8. On the definition of these categories, see below, n. 20. For other national labour markets, see Bruijn and Van Heslinga, 'Seamen's employment', pp. 13-14, and the essays in Van Royen, Bruijn, and Lucassen, eds, "Those emblems of hell”?
} 
Earle have based their work on Davis's figures, or where presenting new material have also tended to offer a brief discussion of average figures. ${ }^{10}$

Davis acknowledged that more experienced men might earn higher wages, and for specialists he gave a comparison of peace and war wages during the early eighteenth century. He pointed out that 'the unspecialised crew...[were] by no means homogenous', noting the gradation of seafarers 'from boy...to chief mate' in 'a series of steps, none of which was very high, though the change in status and earnings which the whole series carried with it was considerable'; but he also stated that the most important distinction was between the master and the rest of the crew. ${ }^{11}$ Cheryl Fury, in her research on the late sixteenth century, noted the variation in wages between merchant seamen as 'free agents' responsible for negotiating their own contracts, adding that 'Seamen's incomes were rarely limited to their wages alone'. ${ }^{12}$ She also argued that skilled seafarers (especially those who had served an apprenticeship) could command higher pay, but her discussion focuses upon a 'maritime elite' of 'skilled shipmasters, pilots and officers', who 'earned much more than unskilled and semiskilled men'. ${ }^{13}$ Marcus Rediker and Marcel van der Linden have separately suggested a three-tiered structure of masters, 'maritime officers and skilled workers', and (by implication unskilled) mariners; Rediker described the latter as 'the largest category of maritime workers...the "people" of the merchant service'. ${ }^{14}$ The prevalent interpretation is thus a relatively rigid labour market in which poor, unskilled workers were commonplace. To test this idea we must analyse the available data in more depth.

\section{TABLE 1 HERE}

\footnotetext{
${ }^{10}$ Andrews, Ships, money and politics, pp. 76; Earle, 'English sailors', pp. 82-4; Earle, Sailors, pp. 29-34; Rediker, Between the devil, pp. 119, 121-24, although Rediker also provides statistics in appendix C, pp. 304-6. Two different approaches are Brooks, 'Wage-scale', and Hair and Alsop, English seamen and traders, pp. 1205; both are small samples from specific sectors of the shipping industry.

${ }^{11}$ Davis, English shipping industry, pp. 113, 126-7; cf. Earle, Sailors, pp. 42-5.

${ }^{12}$ Fury, Tides in the affairs of men, pp. 93-6, 99-100.

${ }^{13}$ Fury, 'Elizabethan maritime community', pp. 117-8; Fury, Tides in the affairs of men, p. 94; see also Loades, 'English maritime community', pp. 10-13.

${ }^{14}$ Rediker, Between the devil, pp. 121, 123-4; Van der Linden, 'Notes from an outsider', p. 354; cf. Bruijn, 'Seafaring in early modern and modern times', pp. 2-3, 6-7.
} 
Davis did not explain how he gathered his figures, but using his original notes we can examine his source material. ${ }^{15}$ For the seventeenth century he based his conclusions on documents from 45 separate years, totalling 2,727 individual wage entries, though there is no apparent methodology as to how Davis selected and assessed this evidence. His notes give the impression of scattered sampling through certain series of the admiralty court records, and in a few cases he recorded no source, or included possible duplications of entries. It is also unclear whether the predominance of entries with no specified rank (62.6 per cent) is due to the documents or to Davis's note-taking, as he tended to record ranks only for specialists, masters, and master's mates. ${ }^{16}$ Finally, Davis collected more evidence for the later period 65 per cent of these wage entries date from 1670 or later. His dataset is therefore best used for comparison with new research.

In deliberate contrast to Davis's broad survey, my approach has focused upon four samples, with an emphasis upon reconstructing lawsuits across the surviving series of the admiralty court's papers, and collecting data on monthly wages. These papers do not directly record the wages paid to seafarers; they represent claims about wages, either by seafarers as plaintiffs or by shipmasters and owners as employers and, usually, defendants. The wage schedules submitted by plaintiffs rarely list a ship's entire crew, and very few cases proceeded to judgment. ${ }^{17}$ Consequently, there is only occasional evidence as to whether litigants received their wages, or how much they were actually paid. Yet seafarers and their employers disagreed over the level of wages in only 6.3 per cent of wage entries that I have compiled, suggesting that exaggeration by plaintiffs was either unusual or routinely went

\footnotetext{
${ }^{15}$ Hereafter referred to as the Davis wage dataset. Davis gave only one footnote, which named no specific sources but stated 'There are many hundreds of wage records in the High Court of Admiralty. They are more ambiguous, and less plentiful, before the mid-seventeenth century than they become later' (Davis, English shipping industry, p. 135, n. 3). The following summary is based on the notes in folders 1, 8, and 47-56 of the Davis papers at the Maritime Historical Studies Centre, University of Hull, and I am very grateful to Colin Heywood for his hospitality and assistance while consulting this collection. The sources Davis drew from were B[ritish] L[ibrary] Add. MS 22,183; TNA HCA 13/74, HCA 13/77, HCA 13/129, HCA 13/130, HCA 13/131, HCA 15/5, HCA 15/6, HCA 15/7, HCA 15/8, HCA 15/9, HCA 15/10, HCA 15/11, HCA 15/12, HCA 15/13, HCA 15/14, HCA 15/17, HCA 15/18, HCA 15/19, HCA 15/32, HCA 15/33, HCA 15/39, HCA 24/114, HCA 24/115, HCA 24/116, HCA 24/117, HCA 24/121, HCA 24/122, HCA 24/123, HCA 24/124, HCA 24/125, HCA 30/635, HCA 30/653, HCA 30/664.

${ }^{16}$ For example, Davis recorded only 31 mariners for the period 1680-9, whereas my research found 107 mariners during 1680-8, from a sample focused around the years 1682-5.

${ }^{17}$ Steckley, 'Litigious mariners', p. 325; see also Blakemore, 'Legal world'.
} 
unchallenged, and these sources remain the best available guide for wages in the shipping industry during this period. ${ }^{18}$

The data come from three studies of four years, 1590-3, 1655-8, and 1682-5, and a longer study of 1644-9, selected primarily on the nature of the sources themselves. The 1640s and 1650s were the busiest period for the admiralty court, and generated the most copious and detailed papers. ${ }^{19}$ The samples of $1644-9$ and 1655-8 therefore provide a core body of evidence with 1590-3 and 1682-5 offering comparative cases and identifying longer trends. However, as the volumes of admiralty court records do not run in neatly confined date ranges, and many cases deal with voyages from previous years, I have also gathered data from the years adjacent to the planned studies. The dataset therefore contains all wage entries found in the sources consulted, from the years 1589-92 (which yielded very few wage statistics), 1640-50, 1651-62, and 1680-90, although in each sample they are clustered most heavily in the four years that formed the original focus of research. ${ }^{20}$

\section{TABLE 2 HERE}

These samples provide 1,746 wage entries across 220 distinct voyages, a smaller but more rigorously compiled body of evidence than Davis's dataset, with relatively little overlap: 229 entries appear in both datasets, 13 for the 1640-1650 sample, 216 for the 16801690 sample. The four samples vary in size and in level of detail, and the 1589-1592 sample produced only 24 entries and is therefore excluded from most of the discussion presented

\footnotetext{
18 The data used in this article is available online at http://humanities.exeter.ac.uk/media/universityofexeter/collegeofhumanities/history/researchcentres/centreforma ritimehistoricalstudies/documents/HCA Wage_Dataset.accdb, accessed 23 June 2016. On disputed wage claims see Blakemore, 'A descriptive report', pp. 6-7. In these disputed cases the lowest value has been used, to minimize the effects of any exaggeration.

${ }^{19}$ Steckley, 'Litigious mariners'; Steckley, 'Merchants and the admiralty court'; Steckley, 'Instance cases'. I am grateful to Colin Greenstreet and the MarineLives project for their assistance with the 1650s material: for more detail see http://www.marinelives.org/wiki/MarineLives, accessed 23 June 2016.

${ }^{20}$ Hereafter referred to as the HCA wage dataset. Documents consulted are: for 1589-92, TNA HCA 3/21, HCA 3/22, HCA 13/28, HCA 13/29, HCA 13/30, HCA 13/96, HCA 13/101, HCA 23/4, HCA 24/57, HCA 24/58, HCA 24/59, HCA 24/60; for 1640-50, HCA 3/41, HCA 3/42, HCA 3/43, HCA 13/59, HCA 13/60, HCA 13/61, HCA 13/62, HCA 13/119, HCA 13/120, HCA 13/121, HCA 13/122, HCA 23/14, HCA 23/30, HCA 24/106, HCA 24/108, HCA 24/109; for 1651-62, HCA 3/46, HCA 3/47, HCA 3/48, HCA 13/70, HCA 13/71, HCA 13/72, HCA 13/127, HCA 13/128, HCA 13/129, HCA 23/18, HCA 24/112, HCA 24/144; for 1672-93, HCA 3/56, HCA 13/78, HCA 13/79, HCA 13/132, HCA 23/22, HCA 24/121. For a more detailed discussion see Blakemore, 'A descriptive report'.
} 
here. Masters and master's mates, numerically the two smallest categories, were the most reliably listed. Masters held personal authority and navigational - and often financial responsibility for the voyage, giving them a unique position aboard. Master's mates also carried out some of these roles, but like the rest of the crew were subordinate to the master. The category 'specialist' follows Davis's terminology, as well as avoiding the military connotations of the term 'officer', which contemporaries also used..$^{21}$ This category includes any individual identified in the sources as performing a specific task aboard ship: obvious examples are the boatswain, gunner, carpenter, or surgeon, and their assistants (also called 'mates'), cooks, and quartermasters. 'Mariner' means any individual identifiably without such a position, including those described as 'boy', 'common man', 'common mariner', 'foremast man', 'ordinary mariner', 'seaman', and 'servant', and for whom no other rank was recorded. ${ }^{22}$ 'Mariner' therefore represents a very broad category which probably combines temporary labourers with 'career' seafarers, but there is insufficient detail in the records to distinguish further.

\section{TABLE 3 HERE}

The data for masters confirm the argument that, economically at least, they formed a separate group. Of the 40 masters appearing in the dataset, 36 claimed 100s. a month or more. ${ }^{23}$ These wages can also be separated by region (although the small numbers mean that caution should be used), and it appears that commanders on voyages to the Indian Ocean were paid the most by a substantial margin, which is understandable given the length, difficulty, and high investment in these voyages. ${ }^{24}$ The other regions seem roughly similar, with 32 masters claiming wages of 100-120s., and with no visible change from the 1640s to

\footnotetext{
${ }^{21}$ Davis, English shipping industry, pp. 110-21; cf. Scammell, 'Manning', pp.143-4, 149-53; Rediker, Between the devil, pp. 122-3.

${ }^{22}$ See Blakemore, 'A descriptive report', pp. 7-10. 'Mariner' and 'seaman' appear as generic terms in the preambles to depositions, but that generic definition has not been adopted in the HCA wage dataset unless there is further detail in the evidence to support it.

${ }^{23}$ Most wages were given in sterling and, for the purposes of calculation and comparison, have been rendered into shillings here. 26 entries were converted from dollars or guilders. See Blakemore, 'A descriptive report', p. 12.

${ }^{24}$ Some voyages involved more than one region and were counted in the region which, as far as it was possible to determine, made up the bulk of the voyage; 'Northern Europe' includes coastal voyages around Britain, as well as the Baltic and the Atlantic coast of Iberia. See Blakemore, 'A descriptive report', pp. 10-12.
} 
the 1680s. By way of comparison, only 40 entries in the other categories represent wages of 80 s. or more; of these, 4 were specialists, 17 were master's mates, while 6 were unspecified entries over 100s., and therefore possibly masters. Because masters are such a small and distinct group, though one that has occupied much scholarly attention, the rest of this section will focus upon the wages of master's mates, specialists, and mariners. ${ }^{25}$

\section{FIGURE 1 HERE}

The situation here is more complex, partly because of the large number of unspecified entries, and to fully comprehend the economic experiences of individual seafarers we must assess the data in a way which recognises extensive diversity in wage levels. Specialists, the largest category, can be broken down further into separate types. These individuals fulfilled a number of roles, and possessed skills that were essential to shipping; indeed, wage disputes involving specialists regularly revolved around whether they had the requisite skills for the job. Figure 1 displays the spread (the scatter plot) and the concentration (the bands, showing the median and the interquartile range) of wages for the seven most common types of specialist, with the remainder grouped under 'other'. ${ }^{26}$ Amongst the lower wage entries are specialists' mates, though these assistants form only 12.9 per cent of all specialists in the dataset, and the wide range for each type is remarkable. This range is due in part to change in wages across the century, but diversity between specialists is also visible in each sample and even within specific ships.

\section{TABLE 4 HERE}

Such variation is clear when we consider the first and third quartiles of the most numerous types of specialist, which indicate the contours of change over time as well as confirming the hierarchy amongst the types, with carpenters and surgeons apparently

\footnotetext{
${ }^{25}$ Senior, 'The master-mariners authority'; Davis, English shipping industry, pp. 126-32 and ch. 8; Scammell, 'Manning', pp. 144-8; Croft, 'English mariners'; Scammell, 'Merchant service master'; Blakemore, 'Navigating culture'.

${ }^{26}$ Figure 1 includes the 2 specialists listed in the 1589-92 sample. 'Other' includes caulkers, clerks, coxswains, pilots, pursers, sailmakers, stewards, and trumpeters.
} 
possessing greater earning potential - perhaps because they could also ply their trades ashore. This was also a dynamic situation. Cooks and quartermasters experienced fluctuating levels across the samples with higher wages claimed in the 1650s; the first quartile returned to roughly its original level in the 1680s, and only a small net rise occurred for the third quartile. Boatswains and gunners follow a similar pattern, but the third quartile for boatswains and the first quartile for gunners ultimately decreased, suggesting that lower wage rates became more numerous. For surgeons, the third quartile decreased overall while the first quartile dropped considerably during the 1650 s but then recovered. By contrast, carpenters witnessed a sustained increase for both the first and third quartiles, indicating a fairly clear rise in wages. This relative shift in the economic position of gunners, in particular, fits what we know about the changing nature of the shipping industry, as the growth of state navies and convoys made defence less important for merchant shipping, while the rise in carpenters' wages perhaps reflects a greater emphasis on the safe handling of cargo. ${ }^{27}$

\section{FIGURE 2 HERE}

\section{TABLE 5 HERE}

Looking at the three categories of master's mate, specialist, and mariner together (discarding both the small 1589-1592 sample and the unspecified entries for the moment) reveals the relationships between the three groups. Figure 2 indicates that - as with different types of specialist - there was a considerable range within each category and some overlap between them. Nevertheless, the third quartile for mariners and the first quartile for specialists form a threshold, indicating that approximately three quarters of mariners earned less than approximately three quarters of specialists, and a similar threshold existed between specialists and master's mates. All three categories witnessed an increase of both first and third quartile from the 1640 s to the $1650 \mathrm{~s}$; these levels stagnated into the $1680 \mathrm{~s}$, but remained higher than the 1640s level, although the increase in the third quartile for mariners is relatively small.

\footnotetext{
${ }^{27}$ Davis, English shipping industry, pp. 59-60; Lucassen and Unger, 'Shipping, productivity’, pp. 26-7; Unger, 'Ship design', pp. 257-8.
} 


\section{FIGURE 3 HERE}

The wide variety in wage claims suggests an extremely complex labour market. To some extent this resulted from the differing conditions of employment within shipping. The length and riskiness of the voyage affected wage levels: this is most evident for the war years of the 1650s (against the Dutch in 1652-4, and the Spanish in 1655-1660), when increased risks were shared across all voyages and therefore pushed wages up. However, conditions were also divergent between regions (see figure 3). As for masters, wages were highest for master's mates in the Indian Ocean, but mariners' median pay was lower there, which might be explained by the monopolistic control of the East India Company, the much larger crews required to deal with high mortality levels, the potential to recruit seafarers in the Indian Ocean itself, or the opportunities for mariners to purchase high-value but low-volume goods (though once again we must be careful due to very small numbers). ${ }^{28}$ The difficulty of finding replacements in the Atlantic, compared with the Mediterranean and Europe, may have placed a greater premium on skilled workers, which would explain the higher median for specialists in that region. The level of risk in a voyage and the supply of and demand for labour in any given port at any given moment were therefore determining factors in the wages that an individual seafarer could demand.

\section{TABLE 6 HERE}

However, variation is visible within specific ships' crews, suggesting that this was due to personal as well as external factors, although the rough thresholds between categories also appear at this level. The evidence about specific individuals is scarce, but key factors would probably be training and experience, strength and practical skills, levels of numeracy and literacy (which were perhaps more widespread amongst seafarers than is often realised), and networks of contacts - in broader terms, an individuals' human capital, and their social

\footnotetext{
${ }^{28}$ Chaudhuri, English East India Company; Chaudhuri, Trading world; Lawson, East India Company; Sharpe, 'Gender at sea'; Stern, Company-State; Fury, 'First English East India Company voyage'. Considerably more attention has been given to the Dutch East India Company; see Lucassen, 'Multinational and its labour force'; Van Rossum, Werkers van de wereld; and the scholarship cited in both.
} 
capital within the maritime community. ${ }^{29}$ In some ways this analysis supports previous historians' interpretations: shipmasters were clearly on a different economic plane, and the labour force was indeed stratified, as shown by the thresholds between categories. Fury's suggestion that apprenticeships affected wages also probably holds true for the seventeenth as well as the sixteenth century, although in his autobiography Edward Barlow was scathing about his own experiences as a seafaring apprentice during the $1650 \mathrm{~s}$ and $1660 \mathrm{~s} .{ }^{30}$ At the same time, the overlap shows that these groups were not entirely distinct economically (and perhaps socially), and the higher wages of some mariners suggest that the hierarchy did not exactly match boundaries between 'skilled' and 'unskilled' workers. In other words, unspecialised mariners were not necessarily unskilled, and might indeed receive a skill premium in their wages. ${ }^{31}$

This accords with the work of social historians concerned with questions of identity and status such as Alexandra Shepard and Mark Hailwood who, while highlighting the pejorative attitudes of the wealthy and the economic insecurity of the poor, have revealed both 'vertical' and 'horizontal' distinctions which existed within the lower rungs of early modern English society. ${ }^{32}$ There is also some similarity with the situation amongst Venetian glass-manufacturing artisans examined by Francesca Trivellato where, she noted, 'a very flexible economic stratification was able to coexist with a rigid hierarchy', and in which individual negotiation was very important. ${ }^{33}$ It seems likely that seamen's wages would fit a more general life-cycle pattern of wealth increasing over time, as individuals acquired expertise, resources and status, but then declining when they lost physical capabilities later in life. ${ }^{34}$

\footnotetext{
${ }^{29}$ Portes, 'Social capital'; see also Van Lottum, Brock, and Sumnall, 'Mobility, migration, and human capital'. On literacy, see Patarino, 'Religious shipboard culture', pp. 178-81; for a study of literacy and numeracy in the later eighteenth century, see Van Lottum and Poulsen, 'Estimating levels'.

${ }^{30}$ Fury, Tides in the affairs of men, p. 94; Barlow, Barlow's journal, I, pp. 29-30.

${ }^{31}$ For a general discussion of skill premium in early modern labour see Zanden, 'Skill premium'; see also Stephenson, 'Pay of labourers, pp. 6-8.

32 Shepard, 'Manhood, credit and patriarchy'; Shepard, Meanings of manhood; Shepard, 'Honesty, worth and gender'; Shepard, 'Poverty, labour, and the language of social description'; Shepard and Spicksley, 'Worth, age and social status'; Hailwood, 'Sociability, work, and labouring identity'; Hailwood, "“The honest tradesman's honour"'.

${ }^{33}$ Trivellato, 'Salaires et justice', p. 253: 'une stratification économique assez flexible pouvait coexister avec une hiérarchie rigide'.

${ }^{34}$ Shepard and Spicksley, 'Worth, age, and social status', pp. 523-7.
} 
Seafarers were conscious of this situation and its complexity. In certain lawsuits, litigants asked witnesses to describe the 'usual' wages for a specific type of voyage, often as a way to reinforce or discredit plaintiffs' claims. These witnesses regularly defined wages according to rank and compared between regions, though their estimates varied. ${ }^{35}$ More importantly, seafarers were aware of the role of individual negotiation, and the existence of divergent opportunities. In 1641 Samuell Colman, an admiralty official, arrested some English seamen who planned to go to Dunkirk because wages were higher there. ${ }^{36}$ George Hunter, who at 39 had been a seafarer for 'about 24 or 25 yeares', deposed in 1689 that wages were 'not governed wholly by custome but according as M[aste]rs and Mariners can best agree together'. ${ }^{37}$ Seafarers' wage levels were therefore dependent on both their own human and social capital and their ability to pursue alternative options within the mobility of their profession: the variety within the wage data suggests that some, at least, were successful at 'playing' the labour market in this fashion.

These circumstances may have changed during this period, at least for mariners. As shown in figure 2 and table 5 there was a degree of convergence around the median across the century. The interquartile range for mariners diminished from $8.5 \mathrm{~s}$. to $7 \mathrm{~s}$. and then just $3.2 \mathrm{~s}$, whereas the interquartile range for specialists expanded continuously, and that for master's mates remained roughly stable apart from a slight rise during the 1650s. This conclusion is tentative because of the very small number of clearly identified mariners compared with unspecified entries. Due to the overlap between categories visible in figures 2 and 3 and table 6 it is impossible to assign unspecified entries to a category with any certainty on the basis of wages alone; some mariners claimed as much as some master's mates (though not usually in the same ship). Even so, the observed threshold at the third quartile for mariners and first quartile for specialists provides a measurement with which to consider the unspecified entries in the 1640-1650, 1651-1662, and 1680-1690 samples, in particular to test the theory of convergence.

\footnotetext{
${ }^{35}$ E.g. TNA HCA 13/122, answer of Gregory Clements, Robert Oxwicke, John Bagnall, and John Jeffryes, 20 September 1649; HCA 13/72, depositions of Christopher Stribling, Edward North, and John Dillick, 13 February 1657[/8], fos 237v-9r; HCA 13/79, depositions of James Callant, 31 July 1689, Roger Smith and Joseph Pickering, 1 August 1689; HCA 13/129, answer of Robert Lewellin, 22 December 1658.

36 TNA HCA 1/50, examination of Samuell Colman, 8 November 1641, fos 108r-v.

${ }^{37}$ TNA HCA 13/79, deposition of George Hunter, 26 September 1689; cf. deposition of William White, 26 September 1689.
} 


\section{TABLE 7 HERE}

The maximum wage claimed by mariners was 55s. in all three samples, while the third quartile rose from $24.5 \mathrm{~s}$. to $33 \mathrm{~s}$. and then dropped to $26 \mathrm{~s}$. Table 7 presents the first and third quartiles for mariners and unspecified entries, then for unspecified entries excluding those above 55s. ('<M. max'), and then excluding those above the third quartile for mariners in that sample ('<M. Q3'). This approach raises problems of identification - ' $<$ M. Q3' almost certainly excludes some mariners claiming higher wages, and both ' $<$ M. max' and ' $<$ M. Q3' probably include some specialists claiming lower wages. Yet, as noted above, it is reasonable to assume that the majority of those below the third quartile for mariners were also mariners and, regardless of which measure is used, the interquartile range for unspecified entries expanded in the 1651-62 sample and then converged in the 1680-90 sample (although in ' $<$ M. Q3' the interquartile range for 1640-50 was already small).

While the conjunction of human or social capital and hiring circumstances may have created opportunities for seafarers at all ranks, it also appears that a degree of 'homogenisation' was taking place within the bottom ranks of seafarers, with increasingly narrow wage ranges available. The most likely explanation for this is the decline in crew sizes as a result of increased productivity in the shipping sector, reducing the variety of employment roles. ${ }^{38}$ Davis's figures suggest that both absolute wage levels and divergence in wages increased once again in the 1690s, during the Nine Years' War (1688-1697), so any convergence in mariners' wages was clearly interrupted by the frequent warfare in early modern Europe, and further research is needed to confirm this pattern over the longer term. This analysis reveals a mobile and fluid labour market, in which earning potential varied greatly according to an individual's skill level and the immediate circumstances of a voyage, suggesting some continuity with the situation Fury identified in the late sixteenth century; but by the end of the seventeenth century opportunities at the lower end of the economic scale

\footnotetext{
${ }^{38}$ Davis, English shipping industry, pp. 59-60; Earle, 'English sailors', pp. 78-80; Earle, Sailors, pp. 7-8; Lucassen and Unger, 'Labour productivity'; Unger, ed., Shipping and economic growth. There may also be a general correlation between economic growth and reduced wage variation: see Zanden, 'Skill premium', pp. 124-6.
} 
may have been narrowing. ${ }^{39}$ To get a full sense of seafarers' earnings during the early modern period, though, we need to do more than analyse wages in depth: we also need to look at the different forms of remuneration that were common in the shipping industry.

\section{II}

Monthly wages were only one payment option for seafarers in medieval and early modern Europe. The two other most common arrangements were wages 'by the voyage', where master and crewmembers agreed in advance upon a single sum to be paid at the end of their employment, and the form known in the Mediterranean as 'a parte' contracts, in which crewmembers received a share of the voyage's profits. ${ }^{40}$ It has generally been assumed that monthly wages eventually replaced these, but alternatives persisted in some sectors and the three were not wholly distinct.

Wages 'by the voyage' remained common on coastal and shorter routes. ${ }^{41}$ Sometimes bonuses were offered as an incentive if the voyage was successful, while members of the same crew might be hired for different forms of payment, at least until the mid-seventeenth century. ${ }^{42}$ The crews of privateering vessels were paid in shares of prizes, although in the earlier part of the seventeenth century armed merchant ships also took advantage of opportunities to seize prizes, meaning that merchant seamen sometimes received shares on top of their wages. ${ }^{43}$ Payment by shares was also common in fishing and whaling voyages, and in some merchant ships. ${ }^{44}$ When fishing off Newfoundland formed the first leg of a

\footnotetext{
${ }^{39}$ Fury, Tides in the affairs of men, pp. 93-6.

${ }^{40}$ Brooks,' Wage-scale', pp. 235-6; Davis, English shipping industry, pp. 133-4; Croft, 'English mariners', p. 253; Rediker, Between the devil, pp. 118-9; Earle, Sailors, pp. 31-2; Abela, 'Sailors' legal rights', pp. 69-73; Addobbati, 'Until the very last nail', pp. 45-9.

${ }^{41}$ See the wage disputes at Hull in Brooks, First order book; Brooks, 'Early judgments'; Brooks, 'Early orders'. 42 TNA HCA 13/101, answer of Hugh Perry, 9 August 1592, fos 229v-30v; HCA 24/60/53; HCA 13/29, deposition of James Cotton, 27 January 1591[/2], fos 388r-9r; HCA 13/30, deposition of Christopher Dobinson, 13 April 1592, fo. 16r; HCA 13/61, depositions of Andrew Dennis, John Terret, and John Packe, 10 May 1649 , fos $432 \mathrm{r}-3 \mathrm{r}$; HCA $3 / 47$, fo. $104 \mathrm{v}$.

${ }^{43}$ Earle, Sailors, p. 31; Andrews, Elizabethan privateering, pp. 41-5; Starkey, British privateering enterprise, pp. 73-8; Fury, Tides in the affairs of men, pp. 102-8, 131 n. 66; Scammell, 'Mutiny in British ships', pp. 342-4. ${ }^{44}$ TNA HCA 13/127, answers of William Basset, 20 and 22 November 1655; cf. HCA 24/112/80. For a particularly well-documented whaling voyage from 1656, see Appleby, "A "voyage to Greenland"; for fishing in general, see Michell, 'European fisheries'; Starkey, Reid, and Ashcroft, eds, England's sea fisheries; Holm, Starkey, and Thór, eds, North Atlantic fisheries; Heywood, 'Beyond Braudel's “northern invasion"?'. For examples in merchant ships, see TNA HCA 13/63, fos 400r-v (I am grateful to Colin Greenstreet for this reference); Stadsarchief Amsterdam, 5075, inv.nr. 3222, fos 319r-20r.
} 
longer trip, often to Iberia or the Mediterranean, the crew received a proportion of the catch (usually between a third and a fifth) for the time spent fishing, and a monthly wage for the rest of the voyage. ${ }^{45}$ The persistence of such hybrid payment forms - this particular arrangement occurred in the 1680s and possibly later - complicates the idea of a straightforward transition from share- to wage-work, and emphasizes the need to examine the broader context of seafarers' earnings. In this seafarers resemble workers ashore, who also received a mixture of wages and other forms of payment. ${ }^{46}$

One of the most important elements in seafarers' remuneration was the longestablished right to food aboard their vessel, which was not only essential as a matter of subsistence, but may have carried symbolic and social significance as well. ${ }^{47}$ Although seamen were not unique in this, as labourers and servants ashore sometimes received food and lodging from their employers, it seems to have been of special importance to seafarers that they got a full 'diet' aboard ship, presumably because they had no alternative while at sea. ${ }^{48}$ There were complaints about bad victuals in merchant ships, and victualing may have been better (or more consistent) in the navy, as Edward Barlow wrote in his autobiography, and William Hodges claimed in the 1690s. ${ }^{49}$ Nevertheless, such complaints reveal not just that bad food was sometimes provided to seafarers, but that this transgressed generally accepted expectations about the quality of food, providing a legitimate grievance and grounds for protest.

\footnotetext{
${ }^{45}$ TNA HCA 24/108/18; HCA 13/119, answers of Oliver Larwell, Lucas Browne, and Hugh Ball, 3 June 1646; cf. answer of Francis Smith, 5 June 1646; HCA 24/109/321; HCA 13/62, depositions of John Wakeham and Ambrose Carter, 22 February 1649[/50], and George Horsfall, 28 March 1650; HCA 13/70, depositions of James Salmon, 24 January 1654[/5], Richard Vaughan, 25 January 1654[/5], and Timothy Newman, 26 January 1654[/5], fos 233r-40r; HCA 13/127, answers of Thomas Brotherick and Roger Hatton, 3 February 1654[/5], and Peter Bartlett and John Tapley, 16 February 1654[/5]; HCA 3/56, fo. 450r, 453v, 462v-3r; HCA 24/121/169. ${ }^{46}$ Woodward, Men at work, pp. 142-69; Kussmaul, Servants, pp. 40-2; Muldrew and King, 'Cash, wages'; Lemire, Business of everyday life, pp. 89-90; Lemire, 'Plebeian commercial circuits', pp. 254-5.

${ }^{47}$ Rediker, Between the devil, pp. 126-9; Earle, Sailors, pp. 86-92; Fury, Tides in the affairs of men, pp. 139-48. For comments on the emotional and symbolic importance of food on twentieth-century Norwegian vessels, see Aubert and Arner, 'Social structure of the ship', p. 204.

${ }^{48}$ Unger, 'Shipping, productivity', p. 30; Kussmaul, Servants, pp. 40-2; Woodward, Men at work, pp. 147-59; Boulton, 'Wage labour', p. 272; Muldrew and King, 'Cash, wages', p. 155.

${ }^{49}$ Barlow, Barlow's journal, I, pp. 425-6; Hodges, An humble representation, p. 10. For examples of complaints aboard food on merchant ships, see TNA HCA 13/59, depositions of Josias Smith, 6 February 1644[/5], and Stephen Biles, 7 February 1644[/5], fos 621v-3v; HCA 24/108/101; HCA 13/61, depositions of William Foulger, Christopher Cole, Richard Denby, and Robert Waugh, 20 January 1647[/8], Thomas Wilbraham, Philip Jourdan, Thomas Webber, and Edward Skamen, 21 January 1647[/8], fos 7v-13v. For naval victualing in the sixteenth century, see Fury, Tides in the affairs of men, pp. 148-58.
} 
There is some scattered evidence as to what victuals cost, allowing a rough assessment of how much food was worth as part of seafarers' remuneration. In 1574, a navy account calculated 'sea victualls' at 6d. per man per day, or 14s. per man for a 28-day month. ${ }^{50}$ Estimates by contemporaries and historians suggest 16-20s. per man per month throughout the seventeenth century, rising to between $19 \mathrm{~s}$. and $23 \mathrm{~s} .6 \mathrm{~d}$. in the early eighteenth century. ${ }^{51}$ These amounts cannot be treated as wage supplements in a simplistic sense, because mariners may still have spent their wages on food, especially if they contributed to household expenditure. Nevertheless, based on these estimates, the value of food as part of seafarers' remuneration appears considerable, and for those receiving lower levels of pay it could be worth almost as much as monthly wages. It is not surprising, from this perspective, that seamen were so ready to complain when victuals did not meet their expectations. There were various other payments associated with specific aspects of commercial shipping which might contribute to seafarers' earnings. Of these 'primage' was probably the most common, a payment by the freighters to the master to be shared out amongst the crew, which may have emerged from 'lowage and stowage', an earlier kind of payment to seamen for loading and unloading cargo. The seventeenth-century term 'primage and average' relates to this payment, and the appearance of standard wording in admiralty court cases suggests that this was common, part of the bundle of charges that freighters had to pay when hiring a ship. ${ }^{52}$

A detailed discussion of primage occurred in a lawsuit concerning a voyage to Brazil, in which the ship's owners claimed that this payment was due to them, not to the master (the

\footnotetext{
${ }^{50}$ TNA SP 12/96, fo. 165 r. The crown's estimates for provisions were often too low: I thank my anonymous reviewer for this observation.

${ }^{51}$ Davis, English shipping industry, pp. 145, 366; Rodger, Wooden world, p. 117. For contemporary estimates, see TNA HCA 13/59, deposition of Christopher Willson, 2 February 1643[/4], fo. 32r, suggesting £80 per month for wages and victuals of a crew of 35; at 1640s median wage levels the wages would come to approximately $£ 50$, resulting in $£ 30$ for victuals, or 17 s. per man. HCA $24 / 106 / 105$ states that when the Hopefull Marye was seized, they had aboard three months' victuals for twelve men worth $£ 40$, or $22.2 \mathrm{~s}$. per man.

52 Brooks, 'Wage-scale', p. 238; Davis, English shipping industry, p. 146; Scammell, 'Manning', pp. 142-3; Fury, Tide in the affairs of men, p. 93; TNA HCA 24/106/288; cf. 274; HCA 13/119, answer of Henry Jones, 14 November 1645; HCA 24/108/228, cf. 227, 354; HCA 24/109/6, 112, 133; HCA 24/112/115; HCA 23/15/48; HCA 13/61, depositions of Peter Jagoe, 3 March 1648, fos 33r-v, William Wood and John Court, 26 July 1648 , fos 132r-3v, and George Lennion, 18 December 1648, fos 218v-19v; HCA 13/121, answers of John Baptista Guyott, 27 May 1648 and 9 February 1684[/9], and William Wheatley, 15 December 1648 and 11 June 1649; cf. Brooks, First order book, pp. 53, 55.
} 
judge, after a three-year case, backed the master). ${ }^{53}$ The master's witnesses listed the amounts paid on voyages to various locations: a Spanish real for every bale from London to Iberia, Italy or Turkey; a real 'upon every duckett freight' to Flanders; four reals per ton from Zante to London, and three reals per ton from Spain to London. ${ }^{54}$ If shared equally amongst the crew, these last two rates would earn about $15 \mathrm{~s}$. and $11 \mathrm{~s}$. per man respectively. ${ }^{55}$ This was 'paid in consideration to oblige the masters \& Companyes of shipps to make good what dammage happeneth by ill stowage', although one opposing witness claimed that crews also 'have commonly private adventures in the ship, w[hi]ch obliges them to the defence thereof' ${ }^{56}$ In another case from 1656, the plaintiffs alleged that primage 'hathe beene constantly allowed...as an encouragem[en]t and reward, and to engage them to satisfie the damadge if any happen', with one witness claiming that both he and his father, also a mariner, had regularly received primage 'over and above their wages'. ${ }^{57}$ In both these cases shipmasters and their employees had a vested interest in presenting 'primage and average' as being 'constantly allowed', and it appears that the amount received by each man was not very much, especially as it is not clear whether the money was split equally or in different amounts according to rank. ${ }^{58}$

Some individuals did receive more generous emoluments, such as John Eaton, hired to serve aboard the Encrease of York in 1677, who was also 'to receive for Pylotage...in her homeward voyage what [th] Merchant would allow', which was $£ 213 \mathrm{~s} .8 \mathrm{~d} .{ }^{59}$ Eaton’s wages are not recorded, but this sum was more than twice the monthly wage of other crewmembers (except the master). There were sometimes other perks: an unnamed master's mate of the Constant Elizabeth Ketch 'had besides his wages a Beaver hatt given him by the Owners for

\footnotetext{
53 TNA HCA 24/112/38; HCA 24/113/187; HCA 23/18/195; HCA 13/127, answer of Joseph Dobbins, 7 July 1655.

${ }^{54}$ Quoting TNA HCA 13/72, deposition of Isaac Woodgreene, 9 November 1657, fos 183r-v; cf. depositions of Cadwallader Cripps, 16 November 1657 and John Wills, 17 November 1657, fos 184r-6r, Thomas Grant, 25 November 1657, fos 189r-91r, Robert Land, 3 February 1657[/8], fos 222r-3r, and John Whaley, 24 April 1658, Roger Paxton, 26 April 1658, Richard Peachie, 28 April 1658, and Francis Hurdidge, 29 April 1658, fos 280v$7 \mathrm{v}$.

55 This calculation is based on the estimate by Willson in $\mathrm{n}$. 50 above, suggesting a crew of 35 for a 260 -ton ship, and assuming 8 reals to the peso and the exchange rate of $£ 1=5$ pesos given at the start of the article. 56 TNA HCA 13/72, deposition of Isaac Woodgreene, 9 November 1657, fos 183r-v; HCA 13/71, deposition of Richard Bere, 6 February 1656[/7], fos 517r-8r.

57 TNA HCA 24/112/203; TNA HCA 13/71, deposition of Thomas Lindsey, 21 August 1656, fos 349v-51v.

${ }^{58}$ Davis, English shipping industry, p. 146.

59 TNA HCA 13/78, deposition of Joseph Ransley, 15 December 1677; cf. deposition of Jeremie Rosendale, 15 December 1677.
} 
his faithfull service'. ${ }^{60}$ These two seem to be exceptional cases, but if primage and other payments were not especially lucrative, they were apparently common to most voyages, and it is worth noting that their proportional value was greater to seafarers receiving lower wages. The tenacity with which seamen demanded these additional payments shows how much they appreciated this part of their income, and how confident they were in their customary rights to it.

These extra payments may sometimes have been cancelled out by wage deductions for damaged or missing goods, which - according to the witnesses quoted above - was what crewmembers agreed to in receiving primage. ${ }^{61}$ Edward Barlow complained that when the owners [of the ship] see that there is damage, and fear to lose thereby, then they lay the fault on the poor seamen...[who] must stand the damage'. ${ }^{62}$ Although ships' masters and owners themselves often pleaded storms as the reason for damage, in some instances wages were indeed docked. For example, after some of the Free Trade's cargo was damaged, the crew 'abated and allowed' $£ 415 \mathrm{~s}$. 2d. out of their wages, about 3 s. per man. ${ }^{63}$

This arrangement resulted from the traditional financial system for shipping, where the crew were paid by the shipmaster out of the freight earned during the voyage. ${ }^{64}$ Many wage cases were related to commercial lawsuits between the freighters and the master about damaged or missing goods, which in turn caused disputes between the master and his employees over consequent reductions in wages. ${ }^{65}$ Indeed, if a ship sank without earning freight, the crew were not entitled to any wages at all, although admiralty judges usually interpreted maritime law in a manner sympathetic to seafarers, awarding wages even when ships had not earned freight. ${ }^{66}$ Masters could also make deductions as punishment for negligence, disobedience, or bad behaviour, which later in the century became formalised in regulations issued by the Trinity House of Deptford and then by national legislation, and was

\footnotetext{
60 TNA HCA 24/121/127. This resembles the Dutch practice of 'kaplaken', see Vanneste, 'Sailing through the Strait', pp. 134-5.

${ }^{61}$ E.g. TNA HCA 3/41, fos 296v, 312v; TNA HCA 24/106/98, 229; HCA 24/109/82; HCA 3/56, fos 6v, 111v, 241v, 455v; HCA 13/78, depositions of Robert Avery and Abraham Austin, 6 August 1679.

62 Barlow, Barlow's journal, I, p. 90.

63 TNA HCA 24/113/246.

${ }^{64}$ Earle, Sailors, pp. 32, 36-7.

${ }^{65}$ E,g. TNA HCA HCA 13/120, answer of Jeremy Blackman, 2 October 1646; 13/122, answer of Samuel Stanton, 27 February 1649[/50]; HCA 3/46, fo. 48r; HCA 3/47, fos 67v, 90v, 103v; HCA 3/56, fos 241v, 249r, $344 v$.

${ }^{66}$ Steckley, 'Litigious mariners', pp. 329-30.
} 
generally upheld by admiralty judges. ${ }^{67}$ On the other hand, the collective punishment of embezzlement, in which (if no culprit was identified) the whole crew contributed proportionally to cover the loss, suggests that an individual who got away with it might recoup their deducted wages and even make a profit from the embezzled goods, although there is no explicit evidence of this. ${ }^{68}$

Due to this complex array of payments and deductions, it is difficult to produce definite conclusions about seafarers' overall income, though it is at any rate clear that there was a high amount of both physical and economic risk involved. Davis suggested that, including food, mariners' wages were probably more generous than those available to other workers. ${ }^{69}$ There is no way to make a direct or exact comparison, as labourers and craftsmen were paid by the day, while seafarers were paid by the month or the voyage, and both were to some extent seasonal and irregular. Seamen worked in continuous shifts when at sea, and were usually paid for the time their ship spent in foreign ports, but probably spent some time unemployed between voyages, or perhaps pursued other trades intermittently; labourers ashore did not work every day and probably experienced shorter but more regular periods without work. Nevertheless, a rudimentary comparison of earning potential can be made by converting seafarers' monthly wages into pence per day, and including an adjustment for food at the rate of 14s. per month in 1589-92, 17s. for 1640-50 and 1651-62, and 20s. for 1680-90 and 1691-99 (see table 8). This approach unfortunately ignores both perks and deductions for workers at sea or ashore, but on this basis, seafarers' nominal wages appear higher than farm labourers' wages, similar to urban wages in the north of England, but uncompetitive with builders' wages paid in London. If food is included in the calculation they look better than northern wages and closer to, but often still below, London wages -

\footnotetext{
${ }^{67}$ Rediker, Between the devil, pp. 120-1; Earle, Sailors, pp. 35-6; Blakemore, 'Legal world', pp. 112-13. For such deductions by admiralty judges, see TNA HCA 3/47, fo. 104v; HCA 3/56, fos 104r, 455v.

${ }^{68}$ Rediker, Between the devil, pp. 129-30. On proportional deductions, see TNA HCA 3/56, fo. 122r; Brooks, First order book, p. 107. Accusations of theft aboard ship seem to have occurred mostly for specific goods stolen from one individual by another, and often concerned money; for example, see HCA 24/106/229, 234; HCA 24/109/123, 225. There were some cases when mariners were caught in the act of embezzling goods: e.g. HCA 13/118, answer of Thomas Graunte \& co, 24 February 1642[/3]; HCA 23/18/398; HCA 13/71, depositions of Thomas Lindsey and John Watson, 21 August 1656, Cornelius Symonson, Jesper Williams, and John Adams, 22 August 1656, fos 349v-60r; HCA 13/128, answer of William Huggery \& co, 22 August 1656; HCA 23/18/164; HCA 24/112/212. Occasionally mariners admitted to stealing and selling goods: Brooks, First order book, pp. 10, 25; Brooks, 'Early judgments', p. 18, 30.

${ }^{69}$ Davis, English shipping industry, pp. 151-2; cf. Scammell, 'Manning', p. 141; Earle, Sailors, p. 34.
} 
although Judy Stephenson has shown that these London series actually represent semi-skilled workers, while unskilled workers were paid about 30 per cent less. ${ }^{70}$

\section{TABLE 8 HERE}

We can also compare the increase in wages for different workers across the century with the Consumer Price Index (CPI) for London compiled by Robert Allen, calculating the CPI as a percentage increase on the 1589-92 level (see figure 4). ${ }^{71}$ Seafarers, as mobile workers, probably spent their money in several places, but the London CPI can be used as a basic measure because it reflects prices in the city where this wage litigation took place and where, if they were successful in court, these seafarers were paid. Urban labourers' and craftsmen's wages roughly doubled what they had been in 1589-92, a broadly similar rate to the CPI (although this graph compares all wages with London prices), whereas farm labourers' wages did not, and seafarers' wages did so only in the 1690s - and such high wartime rates did not continue throughout the eighteenth century, as wages dropped once again during periods of peace. ${ }^{72}$

\section{FIGURE 4 HERE}

Seafarers' annual income was the subject of debate in one admiralty lawsuit in 1647, after George Robinson lost the use of his arm due to an accidental shot from the Pilgrime. ${ }^{73}$ Robinson alleged that 'to get a liuelyhood for himselfe his wife and children [he] hath of late yeares generally gone a Quarterm[aste]r...[and] by carrying some small venture together $\mathrm{w}[\mathrm{i}]$ th his wages' he earned between $£ 60$ and $£ 100$ each year 'besides his dyett', an income of which he was now 'utterly deprived'. ${ }^{74}$ The defendant argued that Robinson would have earned only $£ 13$ a year, while one witness suggested £18; William Lillam, another

\footnotetext{
${ }^{70}$ Stephenson, 'Pay of labourers'. Stephenson's new series for unskilled labourers begins in 1661, so it cannot be used for comparison here.

${ }^{71}$ Allen, 'London'; Allen, 'Great divergence', pp. 419-24.

${ }^{72}$ Davis, English shipping industry, pp. 136-7; Rediker, Between the devil, appendix C, pp 304-5.

${ }^{73}$ Robinson first sued in the Middlesex Sessions of the Peace (London Metropolitan Archives MJ/SR/0995/662, 29 March 1647) and then petitioned the admiralty committee (TNA ADM 7/673, p. 300, 13 May 1647), who referred the case to the admiralty court.

${ }^{74}$ TNA HCA 24/108/61; cf. HCA 23/15/31.
} 
quartermaster, claimed that he earned $£ 40$ annually besides his diet. ${ }^{75}$ These estimates are clearly all strategic within this specific lawsuit, but it is significant that they discount food, and Robinson's and Lillam's claims appear optimistic when considering the available data, especially as seafarers may not have been employed at sea for the full year. Even if Lillam worked for a whole year, his stated wages (35s. per month) would earn him just $£ 2215 \mathrm{~s}{ }^{76}$ Apart from personal motives in the lawsuit, the additional payments discussed above may go some way to explain the high estimates, but Robinson's phrase 'by carrying some small venture' becomes more significant in this context, and this is the final element of seafarers' income to which we shall now turn.

Historians have long recognised that some seafarers engaged in trade, but the regular involvement of seafarers of lower status, and the impact of their activities, is only now receiving detailed attention. ${ }^{77}$ In the papers of the admiralty court there are plentiful examples of specialists and mariners, as well as masters or master's mates, carrying goods with them in their voyages: indeed, too many examples to deal with at length here. Much of this evidence is scattered, as seamen rarely started lawsuits about their goods. More commonly, incidental details about their possessions appear in cases concerning prize, damage, or ships lost at sea. These, like the wage data, represent claims about the value of goods, some of which are very probably inflated or at least optimistic, while others mention no values for the goods at all. It is therefore impossible to provide a comprehensive economic analysis of the practice, but it was apparently ubiquitous.

Local shipmasters' guilds accepted seamen's right to carry trade goods until at least the middle of the seventeenth century, although there were restrictions on certain voyages. In 1621 the Trinity House of Deptford produced a certificate 'that the following portage,

\footnotetext{
75 TNA HCA 13/61, depositions of Edward Mekateur, 2 November 1648, fos 191r-v, William Lillam and William Dunn, 11 November 1648, fo. 196v-7v; HCA 13/120, answer of Joshua Jolly, 7 October 1647.

${ }^{76}$ Calculated at a 28-day month; a calendar year of twelve months would earn $£ 21$.

${ }^{77}$ Brooks, 'Wage-scale', pp. 234-5; Davis, English shipping industry, p. 150; Scammell, 'Manning', pp. 142-3, 146; Croft, 'English mariners', pp. 261-2; Rediker, Between the devil, pp. 130-3; Hair and Alsop, English seamen and traders, pp. 125-32; Earle, 'English sailors', pp. 59-62, 83; Bruijn and Van Heslinga, 'Seamen's employment', p. 14; Scammell, 'Merchant service master', pp. 10-12; Lemire, "'Men of the world"'.
} 
outward and homeward, free of custom, is appropriate': in an eastern Mediterranean voyage, $£ 100$ in goods for the master, $£ 10$ for officers and $£ 5$ for seamen; for the western Mediterranean, France and Iberia, one ton in every 100 for the master, 20 nobles in goods for officers, and 5 marks for seamen; and to the North Sea, the Baltic and Russia, 'according to former custom'. ${ }^{78}$ This last phrase presumably meant the right to carry a 'furthing' of cargo (a word probably related to the Dutch voering), a right which the Trinity House of Hull also respected. ${ }^{79}$ The records of the admiralty court mention similar entitlements. Thomas Browne, master of the Providence in 1672-3, 'was to have the Carriage of a Tunn of goods...freight free'. ${ }^{80}$ Roger Ward, a mariner of the Societye, submitted interrogatories in a lawsuit which claimed that the ship's master had said 'hee would haue his men to carry a venture w[it]h them, for the fraight whereof...hee would not haue a penny and then if they should meete w[i]th any Turkes men of warre they might fight as well for their owne goods as his'. Ward's interrogatories also asked witnesses 'haue they not com[m]only in their voyadges...carryed a venture w[i]thout paying any fraight... and whether it bee not a usuall custome of Marriners soe to doe', and even opposing witnesses admitted that this was so. ${ }^{81}$

Unsurprisingly, throughout the seventeenth century, seafarers' investments depended on the routes they sailed. In the eastern Mediterranean, they purchased currants, oil and silk; in the western Mediterranean and Iberia, they traded in fruit, and in the Baltic they bought tar. Those sailing to the fledgling English colonies in America invested in tobacco, in Brazil they bought sugar, while in West Africa they purchased gold, ivory, and - from the midseventeenth century onwards - slaves. Although the East India Company sought to prohibit private trading and control the flow of commodities, some of its seafarers still purchased calicos and other Indian products. ${ }^{82}$ The goods which seamen carried on their outward voyages were equally varied: clothes, alcohol, pewter, and in one case 'soape Bibles \& pepper'. ${ }^{83}$ Some mariners (as well as higher ranking seafarers) carried more than the amount

\footnotetext{
${ }^{78}$ Harris, ed., Trinity House Transactions, p. 47; it is not clear whether these amounts were for individuals or to be shared amongst the crew.

${ }^{79}$ Brooks, 'Early judgments', pp. 6, 31; Brooks, First order book, pp. 14, 21, 44, 121, 135; on voering, see Vanneste, 'Sailing through the Strait', pp. 135-6.

80 TNA HCA 13/78, deposition of Arthur Mackworth, 3 May 1675.

81 TNA HCA 23/14/278; HCA 13/59, depositions of Thomas Raven, Richard Hurlestone, and Richard Herriforde, 8 April 1644, fos 118r-20v; cf. n. 49 above.

${ }^{82}$ For the eighteenth century see Bowen, "'So alarming an evil"'; Bowen, 'Privilege and profit'.

${ }^{83}$ Quoting TNA HCA 13/60, deposition of Robert Rumes, 8 July 1645, fos 112v-5r.
} 
allowed to them by custom, paying freight and therefore effectively acting as small-scale merchants. $^{84}$

The value of these ventures varied widely. For example, the Algernon exploded in the Thames in December 1643 under suspicious circumstances, after returning from a Mediterranean voyage. ${ }^{85}$ The master and company, 38 in number, apparently had $£ 600-700$ 'in goodes and clothes...moste of her Companye haueing some adventure'. ${ }^{86}$ Moses Hardinge deposed that 'beinge but one of the foremaste men in her' he had only about $£ 2$ aboard, but others had 'a greate deale more and some of them neere to the value of one hundred poundes' ${ }^{87}$ Similarly, after the Alice \& Priscilla was seized, the crew claimed for 'losse of clothes goodes, and tyme loste'; Christopher Mitchell estimated he had lost £50-60, Henry Minor and Nicholas Averye claimed $£ 20$ each, and Thomas Foster 'as goode as tenne poundes' ${ }^{88}$ In another case Marie Carpenter alleged that her husband, the master of the Margarett Bonadventure, and the ship's carpenter (both of whom died during their voyage to the Canaries and Barbados) had carried out adventures initially worth at least $£ 700$ and $£ 100$ respectively, which they had 'much increased' to $£ 1,000$ and over $£ 200 .{ }^{89}$

\section{TABLE 9 HERE}

The records describe the possessions of a whole ship's company in only a very few cases, usually as part of prize proceedings, but they are particularly revealing (see table 9). In 1649 the John Adventure was seized en route to Sanlúcar, and depositions in the resultant case listed the losses of the crew. With unusual detail, Samuel and Robert Bromwell stated that they had possessed 'Three peeces of serges...three ends of dyed fustian... six peeces of coloured bindeing...two grosse of threed laces... Three grosse of threed lace [of better quality]...One bagg of Myrabalins...Two payre of bootes...One Rundlet...Canvas and

\footnotetext{
${ }^{84} \mathrm{I}$ am currently preparing an article on these practices.

${ }^{85}$ TNA HCA 24/106/57; HCA 13/118, answer of Mathew Coachman, 23 February 1643[/4].

${ }^{86}$ TNA HCA 13/59, deposition of John Swifte, 13 February 1643[/4], fos 61r-2r.

${ }^{87}$ TNA HCA 13/59, deposition of Moses Hardinge, 26 February 1643[/4], fos 90v-1v.

${ }^{88}$ TNA HCA 13/59, depositions of Christopher Mitchell, Henry Minor, Thomas Foster, and Nicholas Averye, 14 June 1644 , fos $259 \mathrm{v}-61 \mathrm{v}$.

${ }^{89}$ TNA HCA 24/106/4; cf. HCA 23/15/72. Marie Carpenter also claimed that the defendant, her husband's successor as master, and another mariner had returned with goods worth $£ 200-400$, though neither had taken out a venture worth more than 20s; for the defendants' response, see HCA 13/121, answer of William Martin, 29 December 1648.
} 
packing...seaven Cases of strong waters... Three firkins of butter', in total worth $£ 2412$ s., besides 'Wearing apparell bedding bookes and Instruments' worth $£ 20 .{ }^{90}$ The Eastland Merchant was seized in 1657 by a Spanish ship near Alexandria, and in an allegation submitted to the admiralty court the ship's owners included a note of what the crew had lost in 'goods, Clothes, Bookes, and Instruments'. Twenty years later, the Unity was seized by an Ostend privateer, then taken by a French vessel, and retaken by an Ostend ship; in the admiralty court the company listed their losses. These examples show how, as with wages, master's mates and specialists tended to claim higher losses in goods. Nevertheless, every member of a ship's crew might have some goods aboard their ship, and most of the seafarers in these cases claimed losses worth several months' wages or more. Even if these were personal possessions rather than trading goods, their value remains important considering the function of material assets as both 'stores of potential cash' and 'an index of credit' ${ }^{91}$

The available evidence is very imprecise about how much this activity contributed to seafarers' incomes, but for some it appears to have been a substantial amount. P. E. H. Hair and J. D. Alsop found evidence for seafarers trading in gold in the earliest English voyages to West Africa, in the 1550s-60s, and examined the 'shipboard economy' of credit and services existing between shipmates. ${ }^{92}$ They estimated that had Roger Gardener, gunner of the Minion, lived to collect all his income from the voyage in which he died, he would have 'brought home a tidy sum... his wages constituted only a modest part, his gold slightly more, and the returns from the shipboard economy over one-half of the total. ${ }^{93}$ Similarly, unless William Lillam simply miscalculated - or lied - in the lawsuit concerning George Robinson, then wages made up about half of Lillam's estimated annual earnings in 1647; the rest, presumably, came from alternative remuneration and from trading. In 1655, shipcarpenter Jacob Bowry claimed that he had lost a total of $£ 170$ when his ship, the Chapman, was seized five years before. He reckoned his tools and clothes were worth $£ 20$, while the fish, pease, and tobacco he had aboard amounted to $£ 117$, worth almost 56 months' wages at the $42 \mathrm{~s}$. per month that he claimed. ${ }^{94}$

\footnotetext{
90 TNA HCA 13/70, depositions of Samuel Bromwell and James Godden, 6 September 1654, fos 120r-1r.

${ }^{91}$ Lemire, 'Plebeian commercial circuits', p. 253; Shepard and Spicksley, 'Worth, age, and social status', p. 511; cf. Lemire, Business of everyday life, ch. 4.

${ }^{92}$ Hair and Alsop, English seamen and traders, pp. 125-32.

93 Ibid., pp. 130-1.

94 TNA HCA 13/71, deposition of Jacob Bowrey, 8 January 1655[/6], fos 678r-v.
} 
A similar situation appears in Edward Coxere's rough account for one voyage to Newfoundland and the Mediterranean in 1659, in which he was chief master's mate. ${ }^{95} \mathrm{He}$ borrowed $£ 15$ 'to fit myself with books, instruments, clothes, and a venture. I drove it so near that $[\mathrm{I}]$ made five pounds serve me for conveniences and ten pounds for a venture, which I laid out in several sorts of commodities, which I thought would turn best to account'. ${ }^{96} \mathrm{He}$ received 70s. per month wages, and served for seven or eight months, at the end of which 'I gained between fifty or sixty pounds. I soon paid my debts and had a stock against the next voyage of my own. ${ }^{97}$ His wages would have amounted to between $£ 2410$ s. and $£ 28$, meaning that he earned a profit (minus the $£ 15$ debt) from his 'venture' or other sources of between $£ 7$ and $£ 2010$ s., making between 20 per cent and 45.6 per cent of his total profit from that voyage.

These isolated examples do not prove that all seafarers doubled their wages by trading on the side; but there was the potential for some to do just that. It is significant that three of these examples were specialists and the last was a master's mate - undoubtedly the opportunities for trade were greater for those higher up the maritime hierarchy, and (as with wages) of a different degree altogether for shipmasters. ${ }^{98}$ Edward Barlow wrote of his desire to be appointed master, 'for now I understood the way and the profit which they had, which none else in the ship had or could expect'. ${ }^{99}$ We should not ignore the enormous inequality within the early modern maritime community, or the sometimes desperate poverty which drove seamen to seek work in the first place. At the same time, seafarers of all ranks carried ventures, sometimes acting individually, sometimes in a partnership or syndicate of the ship's company, and it was probably the opportunity to do so - and, perhaps, the apparent possibility of rising to higher ranks and greater opportunities - which made the otherwise unattractive wages and conditions of seafaring a proposition with some appeal. ${ }^{100}$

\footnotetext{
${ }^{95}$ Coxere, Adventures by sea, pp. 40-4, 49-51,

${ }^{96}$ Ibid., p. 80.

${ }^{97}$ Ibid., p. 85 .

${ }^{98}$ For examples of two other master's mates' investments, see TNA HCA 13/71, depositions of Thomas Walker, 4 April 1654, fo. 659r, and William Essex and John Wood, 30 August 1654, fos 672v-3r.

${ }^{99}$ Barlow, Barlow's journal, II, pp. 339-40

100 This is also Earle's conclusion in Sailors, ch. 5, though he says very little on trading opportunities.
} 
Michael Johnson may have had cause to feel pleased with the proceeds from his voyage as the Fame left Sanlúcar for England: but his story does not end there. The 1640s were difficult times, with Britain split in civil war, and seafaring was a dangerous profession. As they sailed home the ship sprang a leak, and 'betwixt Plymouth and Dartmouth' the ship's pump broke. ${ }^{101}$ Unable to keep their vessel afloat, 'fearinge least they should otherwise haue perished in the sea', the crew put into Dartmouth - which, unfortunately for Johnson and his fellows, was then under the control of royalist forces to whom London ships such as the Fame were fair game. The royalists 'made prise of all but the Companyes goodes especiallye such as they had in theire Chests or Cabons'. ${ }^{102}$

Yet again, Johnson proved resourceful. He 'did by a frendes meanes there save his money and his twoe peeces of silke stuffe...unknowen to the seizers'. His shipmate Richard Wall later assured the admiralty court in parliamentarian London that Johnson 'was and is a man very well affected to the Parliament' and refused employment with the royalists. Instead, when his captors placed the cargo from the Fame aboard another ship, the Martha, Johnson volunteered to join the crew 'the better to gett awaye with his money and stuffs'. Along with 'the rest of [the Martha's] Company all but the m[er]chant of her and one passenger', Johnson 'agreed to bringe the said shippe...to some place under the protect[i] on of the Parliament'.

This they did, taking the ship to Hurst Castle at the entrance to the Solent, but Johnson's troubles were not over. The commander of the castle, Captain Baxter, examined the crew and 'tooke from the said Johnson one hundred and fiftye odd peeces of eight which for the preservac[i]on thereof the said Johnson had quilted in his wastcoate...Baxter tooke from him the twoe peeces of silke stuffe... onelye giueinge him somewhat to beare his chardges upp to London'. Still Johnson did not give up. He started a lawsuit against the Martha in the admiralty court, and it is from the depositions of his shipmates on his behalf that we know so much about his 'turneinge and winding' across the Atlantic and back again.

101 TNA HCA 13/59, depositions of Richard Wall and William Gare, 25 April 1645, fos 739r-40r. All quotations in this section are from these depositions.

${ }^{102}$ Despite this slightly ambiguous wording, the implication is clear that the mariners' goods were seized. 
We do not know whether Johnson was successful in his suit, but his experiences in this one voyage are emblematic of the possibilities, the perils, and the pressures in seafaring employment during the early modern period, and particularly on long-distance voyages. Johnson's story represents the natural and political dangers which surrounded all seafarers, but also the ingenuity and doggedness with which some grasped the opportunities that came their way.

Considering the evidence presented here, we must revise the emphasis in previous research upon seafarers as low-skilled wage-workers, although they were certainly at the mercy of economic forces. Even though this was a period of European economic growth growth to which shipping contributed substantially - it was also one of rising inequality between and within social groups. ${ }^{103}$ Seafarers' wages increased more slowly and less consistently than urban labourers' pay did, and stagnated during the eighteenth century, continuing to rise temporarily (and often spectacularly) in wartime but without any sustained overall increase. ${ }^{104}$ Potential 'homogenisation' in the lower ranks of the maritime labour force also suggests that opportunities for mariners were becoming more restricted. As seafarers' work came under stricter regulation by the British state - intended to protect their wages, as well as control their employment - none of this legislation made any mention of their entitlement to primage or to carry ventures, although some seafarers continued to practice private trade throughout the eighteenth century whether it was legal or not, with a substantial impact upon British material culture. ${ }^{105}$

Seafarers were indeed 'proletarian', especially if we adopt recent definitions of that term which emphasize economic insecurity, but describing them in such a way can also obscure the economic agency that they possessed. ${ }^{106}$ The statistical analysis of seafarers' wages shows that, while the labour market was hierarchical, those in the lower ranks included skilled workers able, at times, to benefit from their employment circumstances and their human and social capital. Moreover, wages were not separate from other remuneration:

\footnotetext{
${ }^{103}$ Unger and Lucassen, 'Shipping productivity and economic growth'; Costa, Palma and Reis, 'The great escape?'; Soltow and Van Zanden, Income and wealth inequality; Hoffman, Jacks, Levin and Lindert, 'Sketching the rise'; Shepard and Spicksley, 'Worth, age and gender'.

${ }^{104}$ For the eighteenth century, see the figures given in Davis, English shipping industry, pp. 136-7; Rediker, Between the devil, appendix C, pp 304-5.

105 Blakemore, 'Legal world', pp. 112-3, 117-20; Bowen, "'So alarming an evil”"; Lemire, "“Men of the world"'.

${ }^{106}$ Savage, 'Class and labour history', p. 61; Van der Linden, 'Labour history beyond borders', p. 368.
} 
seafarers themselves saw their income as a parcel including wages, perquisites, and trading opportunities. They worked in a venture economy, in which each voyage carried the potential for profit or loss for merchants, masters, and mariners alike. Seafaring has been described as a 'speculative' occupation during the late medieval period, and the evidence discussed here shows that it remained so throughout the seventeenth century. ${ }^{107}$ For many seafarers this would create an economic cycle of borrowing, voyaging, earning and repaying, and if necessary borrowing again, and there was certainly no guarantee of success. ${ }^{108}$ Coxere described how his wife 'with her own industry kept me out of debt', and the ways in which seafarers' economic agency fitted into broader patterns, into household and communal networks of cash and credit, is a topic which deserves further study. ${ }^{109}$ Nevertheless, not only were many seafarers skilled rather than unskilled workers, many were themselves eager participants in international trade. The 'creative survival' of seafarers, it would seem, could take many different forms. ${ }^{110}$

\footnotetext{
${ }^{107}$ Burwash, English merchant shipping, p. 55; cf. Lucassen, 'Multinational and its labour force', p. 30. ${ }^{108}$ On this point see also Earle, Sailors, pp. 34-5.

${ }^{109}$ Coxere, Adventures by sea, p. 51. On credit, see Muldrew, Economy of obligation; Muldrew and King, 'Cash, wages', esp. p. 166; Fury, Tides in the affairs of men, pp. 97-8, and on family see ch. 5; Sharpe, 'Gender at sea'; Lemire, "'Men of the world”, pp. 307-15; cf. Deceulaer, 'Institutional and cultural change', pp. 45-6. On men and women's work in household economies, see Mendelson and Crawford, Women in early modern England, ch. 5; Shepard, 'Manhood, credit and patriarchy'; Sharpe, 'Gender in the economy'; Shepard, Meanings of manhood, ch. 7; Lemire, Business of everyday life, ch. 2; Lemire, 'Plebeian commercial circuits'. 110 This phrase is used by Rediker, Between the devil, p. 9; cf. Rediker, 'Common seaman', p. 352.
} 


\section{Footnote references}

Abela, J., 'Sailors' legal rights in a Mediterranean hub: the case of Malta', in M. Fusaro, B. Allaire, R. J. Blakemore and T. Vanneste, eds, Law, labour, and empire: comparative perspectives on seafarers, c. 1500-1800 (Basingstoke, 2015), pp. 61-78.

Addobbati, A., 'Until the very last nail: English seafaring and wage litigation in seventeenthcentury Livorno', M. Fusaro, B. Allaire, R. J. Blakemore and T. Vanneste, eds, Law, labour, and empire: comparative perspectives on seafarers, c. 1500-1800 (Basingstoke, 2015), pp. 43-60.

Allen, R. C., 'London' spreadsheet of prices and wages:

http://www.nuffield.ox.ac.uk/People/sites/Allen/Documents/London.xls, accessed 17 March 2015.

Allen, R. C., 'The great divergence in European wages and prices from the middle ages to the first world war', Explorations in Economic History, 38 (2001), pp. 411-47.

Anderson, C., Frykman, N., Van Voss, L., and Rediker, M., 'Mutiny and maritime radicalism in the age of revolution: an introduction', International Journal of Maritime History, 58 (2013), pp. 1-14.

Andrews, K. R., Ships, money and politics: seafaring and naval enterprise in the reign of Charles I (Cambridge, 1991).

Andrews, K. R., Elizabethan privateering: English privateering during the Spanish war, 1585-1603 (Cambridge, 1964).

Appleby, J. C., 'A "voyage to Greenland for the catching of whales": English whaling enterprise in the seventeenth century', International Journal of Maritime History, 9 (1997), pp. 29-49.

Armitage, D., 'The red Atlantic', Reviews in American History, 29 (2001), pp. 479-86.

Aubert, V., and Arner, O., 'On the social structure of the ship', Acta Sociologica, 3 (1959), pp. 200-19.

Barlow, E., Barlow's journal of his life at sea in the king's ships, East and West Indiamen, \& other merchantmen from 1659 to 1703, ed., B. Lubbock (London, 2 vols, 1934).

Blakemore, R. J., 'The HCA wage dataset: a descriptive report': http://humanities.exeter.ac.uk/media/universityofexeter/collegeofhumanities/history/research 
centres/centreformaritimehistoricalstudies/documents/HCA_Wage_Dataset_descriptive_repo rt.docx, accessed 23 June 2016.

Blakemore, R. J., 'The legal world of English sailors, c. 1575-1729', in M. Fusaro, B. Allaire, R. J. Blakemore and T. Vanneste, eds, Law, labour, and empire: comparative perspectives on seafarers, c. 1500-1800 (Basingstoke, 2015), pp. 100-20.

Blakemore, R. J., 'Navigating culture: navigational instruments as cultural artefacts', Journal for Maritime Research, 14 (2012), pp. 31-44.

Boulton, J., 'Wage labour in seventeenth-century London', Economic History Review, 49 (1996), pp. 268-90.

Bowen, H. V., 'Privilege and profit: commanders of East Indiamen as private traders, entrepreneurs and smugglers, 1760-1813', International Journal of Maritime History, 19 (2007), pp. 43-88.

Bowen, H. V., “"So alarming an evil:” smuggling, pilfering and the English East India Company, 1750-1810', International Journal of Maritime History, 14 (2002), pp. 1-31. Brooks, F. W., 'A calendar of the early judgments of Trinity House', Miscellanea $V$ (Yorkshire Archaeological Society, 1951), pp. 1-45.

Brooks, F. W., 'A calendar of early orders from the oath and bond book of the Hull Trinity House', Miscellanea V (Yorkshire Archaeological Society, 1951), pp. 46-67.

Brooks, F. W., 'A wage-scale for seamen, 1546', English Historical Review, 60 (1945), pp. 234-46.

Brooks, F. W., The first order book of the Hull Trinity House, 1632-1665 (Beverley, 1942).

Bruijn, J. R., 'Seafarers in early modern and modern times: change and continuity', International Journal of Maritime History, 17 (2005), pp. 1-16.

Bruijn, J. R., and van Heslinga, E. S., 'Seamen's employment in the Netherlands (c. 1600-c. 1800)', Mariner's Mirror, 70 (1984), pp. 7-20.

Burwash, D., English merchant shipping 1460-1540 (Newton Abbot, 1969).

Chaudhuri, K. N., The trading world of Asia and the English East India Company, 1660-1760 (Cambridge, 1978).

Chaudhuri, K. N., The English East India Company: the study of an early joint-stock company, 1600-1640 (London, 1965). 
Clark, G., 'The long march of history: Farm wages, population, and economic growth, England 1209-1869', Economic History Review, 60 (2007), pp. 97-135.

Costa, L. F., Palma, N., and Reis, J., 'The great escape? The contribution of empire to Portugal's economic growth, 1500-1800', European Review of Economic History, 19 (2015), pp. 1-22.

Coxere, E., Adventures by sea of Edward Coxere, ed. E. H. W. Meyerstein (Oxford, 1945). Croft, P., 'English mariners trading to Spain and Portugal, 1558-1625', Mariner's Mirror, 69 (1983), pp. 251-66.

Davids, K., 'Seamen's organizations and social protest in Europe, c. 1300-1825', International Review of Social History, 39 (1994), pp. 145-69.

Davis, R., The rise of the English shipping industry in the seventeenth and eighteenth centuries (Newton Abbot, 1962).

Deceulaer, H., 'Institutional and cultural change in wage formation: port labour in Antwerp (sixteenth-eighteenth centuries)' in P. Scholliers and L. Schwarz, eds, Experiencing wages: social and cultural aspects of wages forms in Europe since 1500 (Oxford, 2003), pp. 27-52. Dekker, R., 'Labour conflicts and working-class culture in early modern Holland', International Review of Social History, 35 (1990), pp. 377-420.

Denzel, M. A., Handbook of world exchange rates, 1590-1914 (Farnham, 2010).

Earle, P., Sailors: English merchant seamen 1650-1775 (London, 1998).

Earle, P., 'English sailors, 1570-1775' in P. C. van Royen, J. R. Bruijn, and J. Lucassen, eds, 'Those emblems of hell'? European sailors and the maritime labour market, 1570-1870 (St John's, Newfoundland, 1997), pp. 73-92.

Fumerton, P., Unsettled: the culture of mobility and the working poor in early modern England (London, 2006).

Fury, C. A., 'The first English East India Company voyage, 1601-1603: the human dimension', International Journal of Maritime History, 24 (2012), pp. 69-96.

Fury, C. A., 'The Elizabethan maritime community' in C. A. Fury, ed., The social history of English seamen, 1485-1649 (Woodbridge, 2012), pp. 117-39.

Fury, C. A., Tides in the affairs of men: the social history of Elizabethan seamen, 1580-1603 (London, 2002). 
Hailwood, M., “"The honest tradesman's honour”: occupational and social identity in seventeenth-century England', Transactions of the Royal Historical Society, 24 (2014), pp. 79-103.

Hailwood, M., 'Sociability, work, and labouring identity in seventeenth-century England', Cultural and Social History, 8 (2011), pp. 9-29.

Hair, P. E. H., and Alsop, J. D., English seamen and traders in Guinea, 1553-1565: the new evidence of their wills (Lampeter, 1992).

Harris, G. G., ed., Trinity House of Deptford Transactions, 1609-35 (London, 1983).

Heywood, C., 'Beyond Braudel's "northern invasion"? Aspects of the North Atlantic and Mediterranean fish trade in the early seventeenth century', International Journal of Maritime History, 26 (2014), pp. 193-209.

Hodges, W., An humble representation of the seamens misery (London, 1694[/5]).

Hoffman, P. T., Jacks, D. S., Levin, P. A., Lindert, P. H., 'Sketching the rise of real inequality in early modern Europe', in Robert C. Allen, Tommy Bengtsson and Martin Dribe, eds, Living standards in the past: new perspectives on well-being in Asia and Europe (2005), pp. 131-72.

Holm, P., Starkey, D. J., and Thór, J. Th., eds, The North Atlantic fisheries, 1100-1976: national perspectives on a common resource (Esbjerg, 1996).

Jackson, R. P., 'From profit-sailing to wage-sailing: Mediterranean owner-captains and their crews during the medieval commercial revolution', Journal of European Economic History, 16 (1987), pp. 605-28.

Kussmaul, A., Servants in husbandry in early modern England (Cambridge, 1981).

Lawson, P., The East India Company: a history (London, 1993).

Lemire, Beverly, "Men of the world": British mariners, consumer practice, and material culture in an era of global trade, c. 1660-1800', Journal of British Studies, 54 (2015), pp. 288-319.

Lemire, Beverly, 'Plebeian commercial circuits and everyday material exchange in England, c. 1600-1900', in Bruno Blondé, Peter Stabel, Jon Stobart and Ilja Van Damme, eds, Buyers and sellers: retail circuits and practices in medieval and early modern Europe (Turnhout, 2006), pp. 245-66. 
Lemire, Beverly, The business of everday life: gender, practice and social politics in England, c. 1600-1900 (Manchester, 2005).

Linebaugh, P., and Rediker, M., The many-headed hydra: sailors, slaves, commoners, and the hidden history of the revolutionary Atlantic (London, 2000).

Loades, D., 'English maritime community, 1500-1650', in C. A. Fury, ed., The social history of English seamen, 1485-1649 (Woodbridge, 2012), pp. 5-26.

Lucassen, J., 'A multinational and its labor force: the Dutch East India Company, 15951795', International Labor and Working-Class History, 66 (2004), pp. 12-39.

Lucassen, J., 'The international maritime labour market (sixteenth-nineteenth centuries)' in P. C. van Royen, J. R. Bruijn, and J. Lucassen, eds, 'Those emblems of hell'? European sailors and the maritime labour market, 1570-1870 (St John's, Newfoundland, 1997), pp. 11-23. Lucassen, J., and Unger, R. W., 'Labour productivity in ocean shipping, 1450-1875', International Journal of Maritime History, 12 (2000), pp. 127-41.

Lucassen, J., and Unger, R. W., 'Shipping, productivity and economic growth' in R. W. Unger, ed., Shipping and economic growth 1350-1850 (Leiden, 2011), pp. 3-44.

McCusker, J. J., Money and exchange in Europe and America: a handbook (London, 1978). Mendelson, S. and Crawford, P., Women in early modern England, 1550-1720 (Oxford, 1998).

Michell, A. R., 'The European fisheries in early modern history', in E. E. Rich and C. H. Wilson, eds, The Cambridge economic history of Europe volume 5: The economic organization of the early modern world (Cambridge, 1977), pp. 133-84.

Muldrew, C., The economy of obligation: the culture of credit and social relations in early modern England (Basingstoke, 1998).

Muldrew, C., and King, S., 'Cash, wages and the economy of makeshifts in England, 16501800', in P. Scholliers and L. Schwarz, eds, Experiencing wages: social and cultural aspects of wages forms in Europe since 1500 (Oxford, 2003), pp. 155-80.

O’Hara, G., "“The sea is swinging into view”: modern British maritime history in a globalised world', English Historical Review, 124 (2009), pp. 1109-34.

Oppenheim, M., A history of the administration of the royal navy and of merchant shipping (London, 1896). 
Oxford English Dictionary: OED Online, December 2014, www.oed.com. Consulted 18 February 2015.

Patarino jr, V. V., 'The religious shipboard culture of sixteenth and seventeenth-century English sailors', in C. A. Fury, ed., The social history of English seamen, 1485-1649 (Woodbridge, 2012), p. 141-92.

Pérez-Mallaina, P. E., Spain's men of the sea: daily life in the Indies fleet in the sixteenth century, trans. C. Rahn Phillips (London, 1998).

Pond, S. 'The Spanish dollar: the world's most famous silver coin', Bulletin of the Business Historical Society, 15 (1941), pp. 12-16.

Portes, A., 'Social capital: its origins and applications in modern sociology', Annual Review of Sociology, 24 (1998), pp. 1-24.

Rediker, M., 'The common seaman in the histories of capitalism and the working class', International Journal of Maritime History, 1 (1989), pp. 337-57.

Rediker, M., Between the devil and the deep blue sea: merchant seamen, pirates and the Anglo-American maritime world, 1700-1750 (Cambridge, 1987).

Rodger, N. A. M., The wooden world: an anatomy of the Georgian navy (London, 1986). Savage, M., 'Class and labour history' in M. van der Linden and L. H. van Voss, eds, Class and other identities: gender, religion, and ethnicity in the writing of European labour history (Oxford, 2002), pp. 55-72.

Scammell, G. V., 'The merchant service master in early modern England', in G. V.

Scammell, Seafaring, sailors and trade, 1450-1750 (Aldershot, 2003), pp. 1-22.

Scammell, G. V., 'Mutiny in British ships, c. 1500-1750', in G. V. Scammell, Seafaring, sailors and trade, 1450-1750 (Aldershot, 2003), pp. 337-54.

Scammell, G. V., 'Manning the English merchant service in the sixteenth century', Mariner's Mirror, 56 (1970), pp. 131-54.

Senior, W., 'The master-mariners authority', The Law Quarterly Review, 136 (1918), pp. 347-56.

Sharpe, Pamela. 'Gender at sea: women and the East India Company in seventeenth-century London', in Penelope Lane, Neil Raven and K. D. M. Snell, eds, Women, work and wages in England, 1600-1850 (Woodbridge, 2004), pp. 47-67. 
Sharpe, Pamela. 'Gender in the economy: female merchants and family businesses in the British Isles, 1600-1850', Histoire Sociale / Social History, 34 (2001), pp. 283-306.

Shepard, A., 'Poverty, labour and the language of social description in early modern England', Past \& Present, 201 (2008), pp. 51-95.

Shepard, A., 'Honesty, worth and gender in early modern England, 1560-1640', in H. French and J. Barry, eds, Identity and agency in English society, 1500-1800 (Basingstoke, 2004), pp. 87-106.

Shepard, A., Meanings of manhood in early modern England (Oxford, 2003).

Shepard, A., 'Manhood, credit and patriarchy in early modern England, c. 1580-1640', Past \& Present, 167 (2000), pp. 75-106.

Shepard, A., and Spicksley, J., 'Worth, age and social status in early modern England', Economic History Review, 64 (2011), pp. 493-530.

Soltow, L., and Van Zanden, J. L., Income and wealth inequality in the Netherlands $16^{\text {th }}-20^{\text {th }}$ century (Amsterdam, 1998).

Starkey, D. J., British privateering enterprise in the eighteenth century (Exeter, 1990).

Starkey, D. J., Reid, C., and Ashcroft, N., eds, England's sea fisheries: the commercial sea fisheries of England and Wales since 1300 (London, 2000).

Steckley, G. F., 'Litigious mariners: wages cases in the seventeenth-century admiralty court', Historical Journal, 42 (1999), pp. 315-45.

Steckley, G. F., 'Instance cases at admiralty in 1657: a court "packed up with sutors"', The Journal of Legal History, 7 (1986), pp. 68-83.

Steckley, G. F., 'Merchants and the admiralty court during the English revolution', The American Journal of Legal History, 22 (1978), pp. 137-75.

Stephenson, J., 'The pay of labourers and unskilled men on London building sites, 16601770' (online paper,

https://www.academia.edu/23668168/The_pay_of_labourers_and_unskilled_men_on_Londo n_building_sites_1660_1770, accessed 29 March 2016).

Stern, P. J., The company-state: corporate sovereignty and the early modern foundation of the British Empire in India (Oxford, 2011).

Trivellato, F., 'Salaires et justice dans les corporations vénitiennes au XVIIe siècle : les cas des manufactures de verre', Annales. Histoire, Sciences Sociales, 54 (1999), pp. 245-273. 
Unger, R. W., ed., Shipping \& economic growth 1350-1850 (Leiden, 2011).

Unger, R. W., 'Ship design and energy use, 1350-1875', in R. W. Unger, ed., Shipping \& economic growth 1350-1850 (Leiden, 2011).

Unger, R. W., 'Regulation and organization of seamen in the Netherlands and Germany before the industrial revolution' in R. W. Unger, eds, Ships and shipping in the North Sea and Atlantic, 1400-1800 (Aldershot, 1997), pp. 66-74.

Van der Linden, M., 'Labour history beyond borders' in J. Allen, A. Campbell, and J.

McIlroy, eds, Histories of labour: national and international perspectives (Pontypool, 2010), pp. 353-83.

Van der Linden, M., 'Notes from an outsider', in P. C. van Royen, J. R. Bruijn, and J. Lucassen, eds, 'Those emblems of hell'? European sailors and the maritime labour market, 1570-1870 (St John's, Newfoundland, 1997), pp. 349-62.

Van Lottum, J., Brock, A., and Sumnall, C., 'Mobility, migration, and human capital in the long eighteenth century: the life of Joseph Anton Ponsaing', in M. Fusaro, B. Allaire, R. J. Blakemore and T. Vanneste, eds, Law, labour, and empire: comparative perspectives on seafarers, c. 1500-1800 (Basingstoke, 2015), pp. 158-76.

Van Lottum, J., Lucassen, J., and Van Voss, L. H., 'Sailors, national and international labour markets and national identity, 1600-1850', in R. W. Unger, ed., Shipping and economic growth 1350-1850 (Leiden, 2011), pp. 309-51.

Van Lottum, J., and Poulsen, B., 'Estimating levels of numeracy and literacy in the maritime sector of the North Atlantic in the late eighteenth century', Scandinavian Economic History Review, 59 (2011), pp. 67-82.

Vanneste, T., 'Sailing through the Strait: seamen's professional trajectories from a segmented labour market in Holland to a fragmented Mediterranean', in M. Fusaro, B. Allaire, R. J. Blakemore and T. Vanneste, eds, Law, labour, and empire: comparative perspectives on seafarers, c. 1500-1800 (Basingstoke, 2015), pp. 123-40.

Van Rossum, M., Werkers van de wereld: globalisering, arbeid en interculturele ontmoetingen tussen Aziatische en Europese zeelieden in dienst van de VOC, 1600-1800 (Hilversum, 2014).

Van Rossum, M., Van Voss, L. H., Van Lottum, J., and Lucassen, J., 'National and international labour markets for sailors in European, Atlantic and Asian waters, 1600-1850' 
in M. Fusaro and A. Polónia, eds, Maritime History as Global History (St John's, Newfoundland, 2010), pp. 47-72.

Van Royen, P. C., 'The "national" maritime labour market: looking for common characteristics', in P. C. van Royen, J. R. Bruijn, and J. Lucassen, eds, 'Those emblems of hell'? European sailors and the maritime labour market, 1570-1870 (St John's, Newfoundland, 1997), pp. 1-9.

Van Royen, P. C., Bruijn, J. R., and Lucassen, J., eds, 'Those emblems of hell'? European sailors and the maritime labour market, 1570-1870 (St John's, Newfoundland, 1997). Woodward, D., Men at work: labourers and building craftsmen in the towns of northern England, 1450-1750 (Cambridge, 1995).

Zanden, J. L. van, 'The skill premium and the great divergence', European Review of Economic History, 13 (2009), pp. 121-53. 
Table 1 - Wage entries in the Davis Papers, 1634-1699

\begin{tabular}{|c|c|c|c|c|c|c|c|c|c|c|c|}
\hline \multicolumn{12}{|c|}{ Table 1 - Wage entries in the Davis Papers, 1634-1699 } \\
\hline \multirow[t]{2}{*}{ Years } & \multirow[t]{2}{*}{ Entries } & \multicolumn{5}{|c|}{ Regions } & \multicolumn{5}{|c|}{ Categories } \\
\hline & & Atlantic & $\begin{array}{l}\text { Indian } \\
\text { Ocean }\end{array}$ & Mediterranean & $\begin{array}{l}\text { Northern } \\
\text { Europe }\end{array}$ & Unspecified & Master & $\begin{array}{l}\text { Master's } \\
\text { mate }\end{array}$ & Specialist & Mariner & Unspecified \\
\hline $1634-7$ & 176 & 0 & 0 & 146 & 4 & 26 & 5 & 11 & 55 & 0 & 105 \\
\hline 1647 & 69 & 13 & 0 & 56 & 0 & 0 & 1 & 1 & 5 & 0 & 62 \\
\hline $1651,1654-6,1659$ & 226 & 79 & 0 & 68 & 0 & 79 & 6 & 16 & 40 & 2 & 162 \\
\hline $1660-5,1669$ & 474 & 48 & 0 & 78 & 97 & 251 & 6 & 19 & 66 & 12 & 371 \\
\hline $1670-3,1675-9$ & 525 & 51 & 0 & 102 & 186 & 186 & 27 & 31 & 99 & 19 & 349 \\
\hline $1680-9$ & 801 & 241 & 12 & 94 & 62 & 392 & 23 & 48 & 238 & 31 & 461 \\
\hline $1690-3,1695-9$ & 456 & 113 & 22 & 59 & 23 & 239 & 11 & 27 & 99 & 121 & 198 \\
\hline Total & 2727 & 545 & 34 & 603 & 372 & 1173 & 79 & 153 & 602 & 185 & 1708 \\
\hline
\end{tabular}

Sources: Davis wage dataset.

\begin{tabular}{|c|c|c|c|c|c|c|c|c|c|c|c|}
\hline \multirow{3}{*}{ Sample } & \multirow{3}{*}{ Entries } & \multicolumn{9}{|c|}{ Table 2 - Wage entries in the HCA wage dataset, 1589-1690 } & \multirow[b]{3}{*}{ Unspecified } \\
\hline & & \multicolumn{4}{|c|}{ Regions } & & \multicolumn{4}{|c|}{ Categories } & \\
\hline & & Atlantic & Indian C & Mediterranean & Northern Eı & Unspecified & Master & Master's m & Specialist & Mariner & \\
\hline $1589-1592$ & 24 & 0 & 0 & 20 & 4 & 0 & 0 & 1 & 2 & 1 & 20 \\
\hline $1640-1650$ & 858 & 131 & 190 & 301 & 59 & 177 & 13 & 22 & 77 & 19 & 727 \\
\hline $1651-1662$ & 339 & 117 & 41 & 83 & 41 & 57 & 7 & 13 & 67 & 35 & 217 \\
\hline $1680-1690$ & 525 & 210 & 13 & 110 & 36 & 156 & 20 & 55 & 148 & 108 & 194 \\
\hline Total & 1746 & 458 & 244 & 514 & 140 & 390 & 40 & 91 & 294 & 163 & 1158 \\
\hline
\end{tabular}

Sources: HCA wage dataset. 
Table 3 - Masters' monthly wages by region (shillings), 1640-1690

\begin{tabular}{|l|l|l|l|l|l|l|}
\hline & Atlantic & Indian Ocea & Mediterranean & Northern Eur & Unspecified & All Masters \\
\hline Number & 22 & 4 & 4 & 3 & 7 & 40 \\
\hline Minimum & 40.0 & 166.6 & 80.0 & 80.0 & 100.0 & 40.0 \\
Median & 120.0 & 200.0 & 115.0 & 110.0 & 100.0 & 120 \\
Mode & 120.0 & 200.0 & 120.0 & N/A & 100.0 & 120 \\
Maximum & 120.0 & 200.0 & 120.0 & 120.0 & 120.0 & 200 \\
\hline
\end{tabular}

Sources: HCA wage dataset. 
Venture economy of early modern seafaring

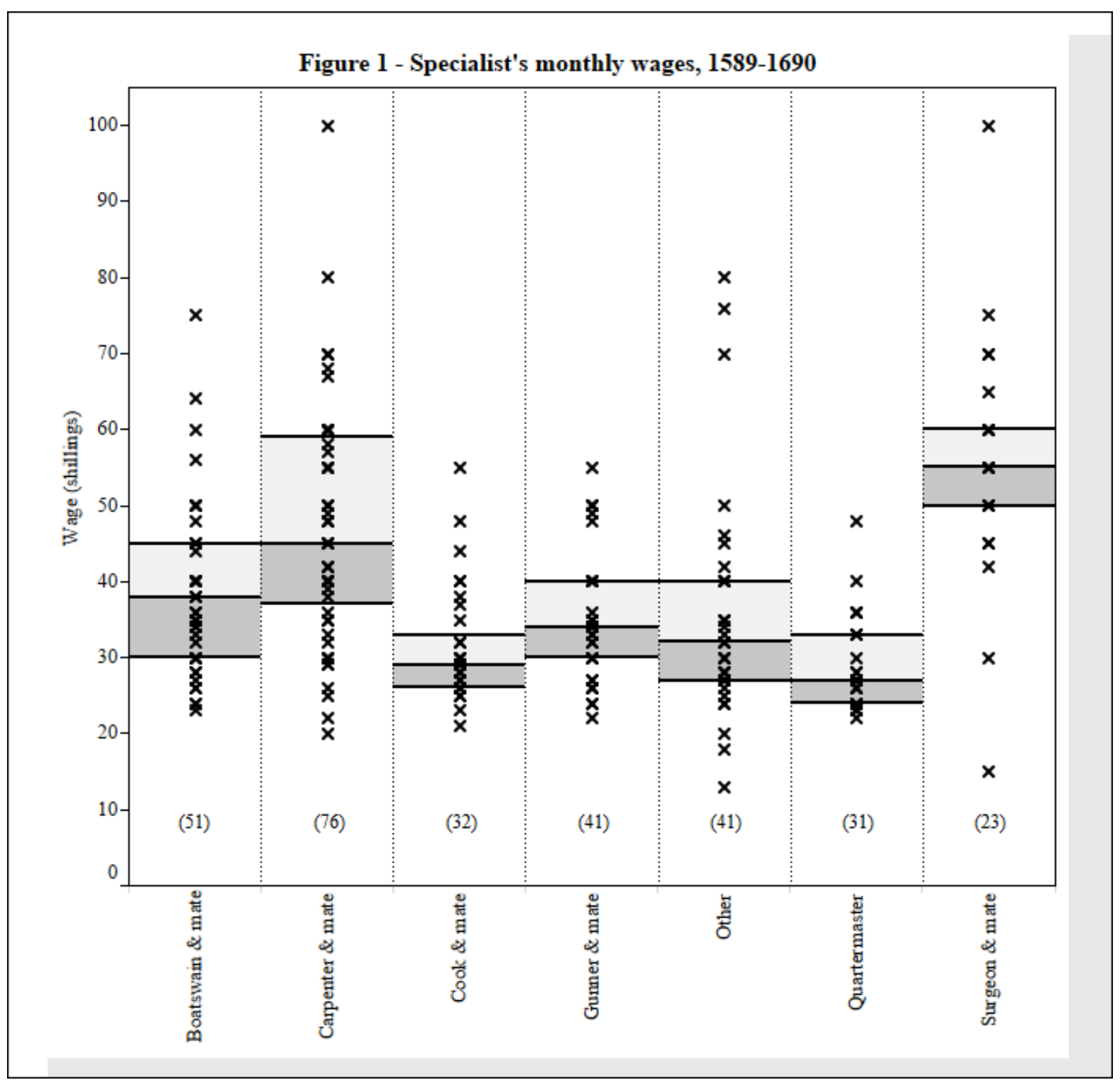

Sources: HCA wage dataset. 


\begin{tabular}{|ll|lll|}
\hline \multicolumn{5}{|l}{ Table 4 - Specialists' monthly wages (shillings), first and third quartile, 1640-1690 } \\
\hline Sample & & $\mathbf{1 6 4 0 - 5 0}$ & $\mathbf{1 6 5 1 - 6 2}$ & $\mathbf{1 6 8 0 - 9 0}$ \\
\hline Boatswain \& mate & Number & 10 & 13 & 28 \\
& Q1 & 30.8 & 40.0 & 30.0 \\
& Q3 & 39.5 & 50.0 & 35.5 \\
\hline Carpenter \& mate & Number & 20 & 14 & 41 \\
\cline { 2 - 5 } & Q1 & 30.0 & 40.5 & 42.0 \\
& Q3 & 40.0 & 60.0 & 60.0 \\
\hline Cook \& mate & Number & 5 & 7 & 20 \\
& Q1 & 26.0 & 27.8 & 26.8 \\
& Q3 & 28.0 & 42.0 & 30.0 \\
\hline Gunner \& mate & Number & 11 & 8 & 21 \\
\cline { 2 - 5 } & Q1 & 33.0 & 38.0 & 27.0 \\
& Q3 & 37.5 & 49.3 & 40 \\
\hline Quartermaster & Number & 8 & 9 & 14 \\
\cline { 2 - 5 } & Q1 & 23.0 & 33.0 & 23.8 \\
& Q3 & 26.3 & 36.0 & 27.0 \\
\hline Surgeon \& mate & Number & 9 & 7 & 7 \\
& Q1 & 50.0 & 36.0 & 52.5 \\
& Q3 & 65.0 & 55.0 & 60.0 \\
\hline
\end{tabular}

Sources: HCA wage dataset. 


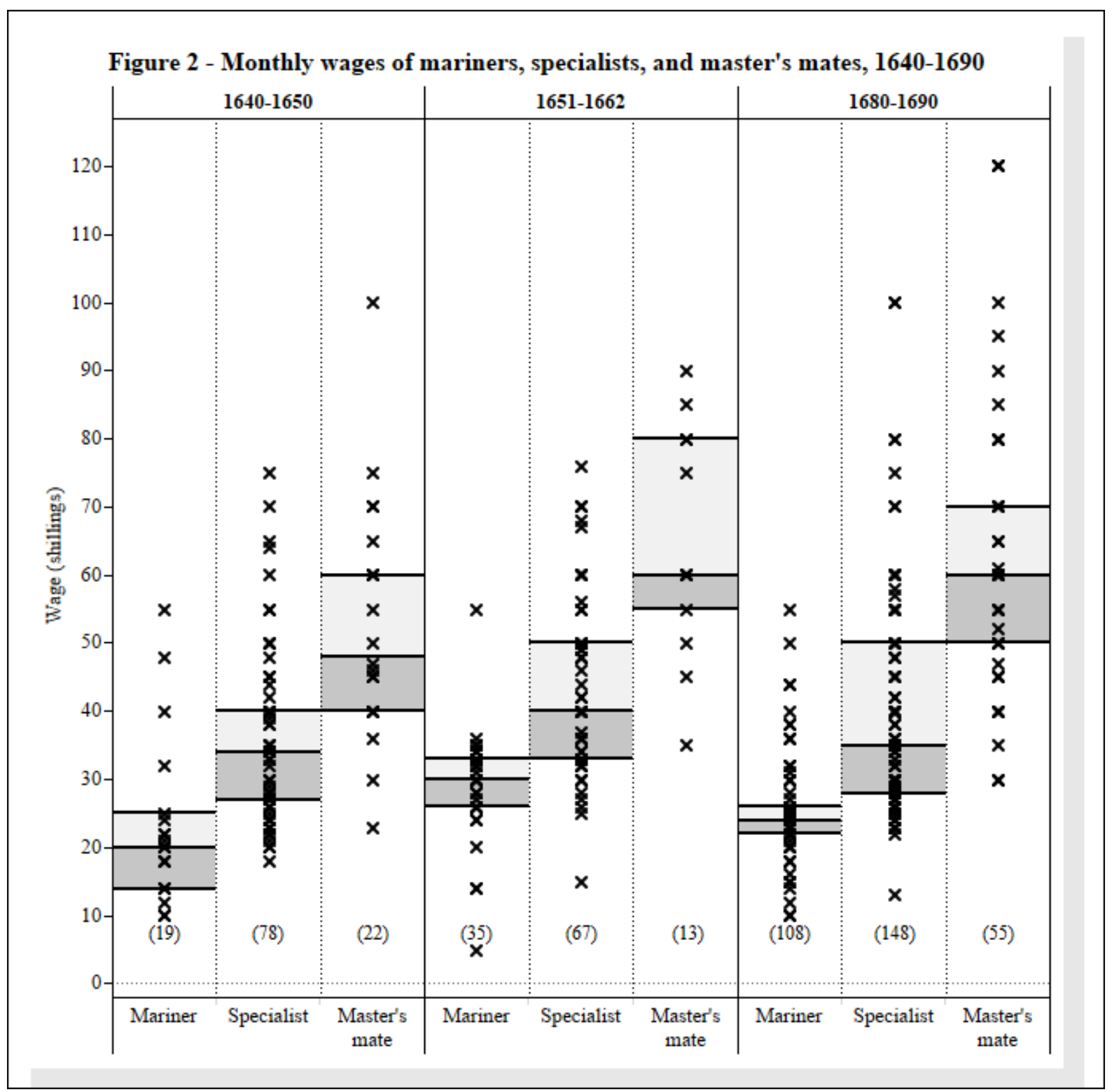

Sources: HCA wage dataset. 
Table 5 - Monthly wages of mariners, specialists, and master's mates (shillings), first and third quartile, 1640-1690

\begin{tabular}{|ll|ccc|}
\hline Samples & & $\mathbf{1 6 4 0 - 5 0}$ & $\mathbf{1 6 5 1 - 6 2}$ & $\mathbf{1 6 8 0 - 9 0}$ \\
\hline Mariner & Number & 19 & 35 & 108 \\
& $\mathrm{Q} 1$ & 16.0 & 26.0 & 22.8 \\
& $\mathrm{Q} 3$ & 24.5 & 33.0 & 26 \\
\hline Specialist & Number & 78 & 67 & 148 \\
& $\mathrm{Q} 1$ & 27.0 & 33.5 & 28.0 \\
& $\mathrm{Q} 3$ & 40.0 & 50.0 & 50.0 \\
\hline \multirow{3}{*}{ Master's mate } & Number & 22 & 13 & 55 \\
& Q1 & 40.0 & 55.0 & 50.0 \\
& Q3 & 60.0 & 80.0 & 70.0 \\
\hline
\end{tabular}

Sources: HCA wage dataset. 


\section{Venture economy of early modern seafaring}

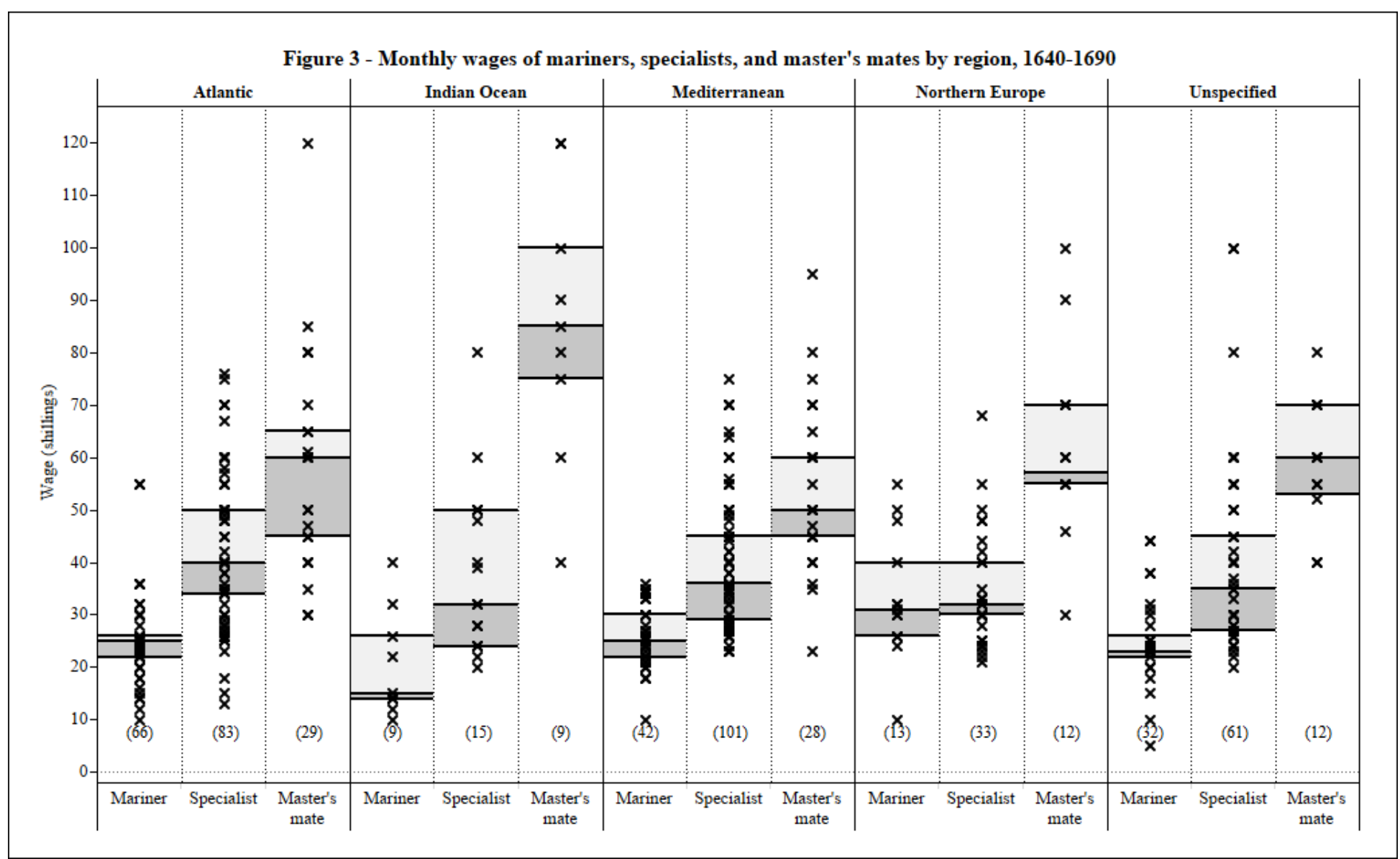

Sources: HCA wage dataset. 


\begin{tabular}{|c|c|c|c|c|c|c|c|c|c|c|c|}
\hline \multirow[t]{2}{*}{ Ship (vge no) } & \multirow[t]{2}{*}{ Year } & \multirow[t]{2}{*}{ Region } & \multirow{2}{*}{$\begin{array}{l}\text { Total } \\
\text { Crew }\end{array}$} & \multicolumn{2}{|l|}{ Mariner } & \multicolumn{2}{|c|}{ Specialist } & \multicolumn{2}{|c|}{ Master's mate } & \multicolumn{2}{|c|}{ Unspecified } \\
\hline & & & & Number & Range & Number & Range & Number & Range & Number & Range \\
\hline Lewes (8) & 1641 & Mediterannean & 34 & 2 & 18 & 5 & $23-70$ & - & - & 27 & $18-70$ \\
\hline Algernon (13) & 1641 & Mediterannean & 21 & - & - & 7 & $24.5-40$ & 1 & 23 & 12 & $21-32$ \\
\hline Sunn (26) & 1643 & Indian Ocean & 88 & 6 & $10-40$ & 9 & $20-40$ & 3 & $40-100$ & 70 & $10-120$ \\
\hline Arke (46) & 1648 & Northern Europe & 35 & 1 & 10 & 14 & $21.3-50$ & 3 & $30-60$ & 17 & $15-35$ \\
\hline St Peeter (77) & 1654 & Mediterannean & 30 & 12 & $24-35$ & 14 & $32-70$ & 1 & 60 & 3 & $30-80$ \\
\hline Agreement (84) & 1654 & Atlantic & 13 & - & - & 7 & $40-67$ & 1 & 85 & 5 & $35-40$ \\
\hline Morning Starre (109) & 1656 & Atlantic & 10 & 6 & $14-30$ & 4 & $40-76$ & - & - & - & - \\
\hline Elizabeth \& Dorothy (114) & 1656 & Northern Europe & 10 & 2 & 32 & 6 & $25-42$ & - & - & 2 & 34 \\
\hline Loyall Charles (159) & 1681 & Atlantic & 13 & 7 & $18-24$ & 4 & $25-45$ & 2 & $60-65$ & - & - \\
\hline Golden Fleece (170) & 1682 & Mediterannean & 12 & - & - & 7 & $27-75$ & 1 & 95 & 4 & $22-24$ \\
\hline Blossome (174) & 1682 & Mediterannean & 12 & 4 & $10-25$ & 5 & $27-60$ & 2 & $45-50$ & 1 & 10 \\
\hline Laurell (224) & 1685 & Mediterannean & 37 & 2 & $23-24$ & 12 & $23-55$ & 1 & 60 & 21 & $20-27$ \\
\hline Royall Oak (225) & 1685 & Atlantic & 11 & 6 & $25-32$ & 5 & $32-40$ & - & - & - & - \\
\hline
\end{tabular}

Souces: HCA Wage dataset. 


\begin{tabular}{|l|lccc|}
\hline $\begin{array}{l}\text { Table 7 - Monthly wages of mariners and unspecified entries (shillings), first and third } \\
\text { quartile, 1640-1690 }\end{array}$ & & \multicolumn{1}{l|}{} \\
\hline Samples & Number & $1640-50$ & $\mathbf{1 6 5 1 - 6 2}$ & $\mathbf{1 6 8 0 - 9 0}$ \\
\hline Mariner & Q1 & 16.0 & 35 & 108 \\
& Q3 & 24.5 & 26.0 & 22.9 \\
& Number & 726 & 33.0 & 25.3 \\
\hline Unspecified & Q1 & 20.0 & 217 & 194 \\
& Q3 & 27.8 & 28.0 & 24.0 \\
& Number & 695 & 40.0 & 27.8 \\
\hline Unspecified <M. max & Q1 & 20.0 & 195 & 187 \\
& Q3 & 26.0 & 28.0 & 23.0 \\
& Number & 449 & 40.0 & 27.0 \\
\hline Unspecified <M. Q3 & Q1 & 20.0 & 92 & 139 \\
& Q3 & 22.0 & 23.0 & 23.0 \\
& & & 30.0 & 25.0 \\
\hline
\end{tabular}

Sources: HCA wage dataset. 


\begin{tabular}{|l|ccccc|}
\hline \multicolumn{7}{|l|}{ Table 8 - Daily wages ashore and at sea (pence), } & $\mathbf{1 5 8 9 - 1 6 9 3}$ & & & \\
\hline Samples & $\mathbf{1 5 8 9 - 9 2}$ & $\mathbf{1 6 4 0 - 5 0}$ & $\mathbf{1 6 5 1 - 6 2}$ & $\mathbf{1 6 8 0 - 9 0}$ & $\mathbf{1 6 9 1 - 9 9 *}$ \\
\hline Mariner (nominal) & 8.1 & 7.7 & 12.9 & 10.7 & 17.1 \\
Mariner (adjusted) & 14.1 & 15.0 & 20.1 & 19.3 & 25.7 \\
\hline Labourer (northern) & 6.5 & 10.7 & 10.8 & 12.1 & 12.0 \\
Building labourer (London) & 10.0 & 18.0 & 20.0 & 20.0 & 24.0 \\
\hline Specialist (nominal) & 11.8 & 17.1 & 17.1 & 12.9 & 21.4 \\
Specialist (adjusted) & 17.8 & 24.4 & 24.4 & 21.4 & 30 \\
\hline Craftsman (northern) & 10.0 & 17.7 & 18.2 & 20.7 & 20.2 \\
Building craftsman (London) & 16.0 & 30.0 & 30.0 & 30.0 & 30.0 \\
\hline Farm labourer (estimated average) & 6.7 & 9.4 & 10.1 & 10.2 & 9.7 \\
\hline
\end{tabular}

Sources: HCA wage dataset and Davis wage dataset $(*)$ for mariner and specialist; Boulton, 'Wage labour', table 1, for London building labourer and craftsman; Allen, 'London', for northern labourer and craftsman, averaged across sample years; Clark, 'Long march', table ? for farm labourer. Labels are used as presented in the sources. Modal wages for mariner and specialist have been used to match Boulton's figures, and have been converted, before and after adjustment for food, assuming a 28-day month. 


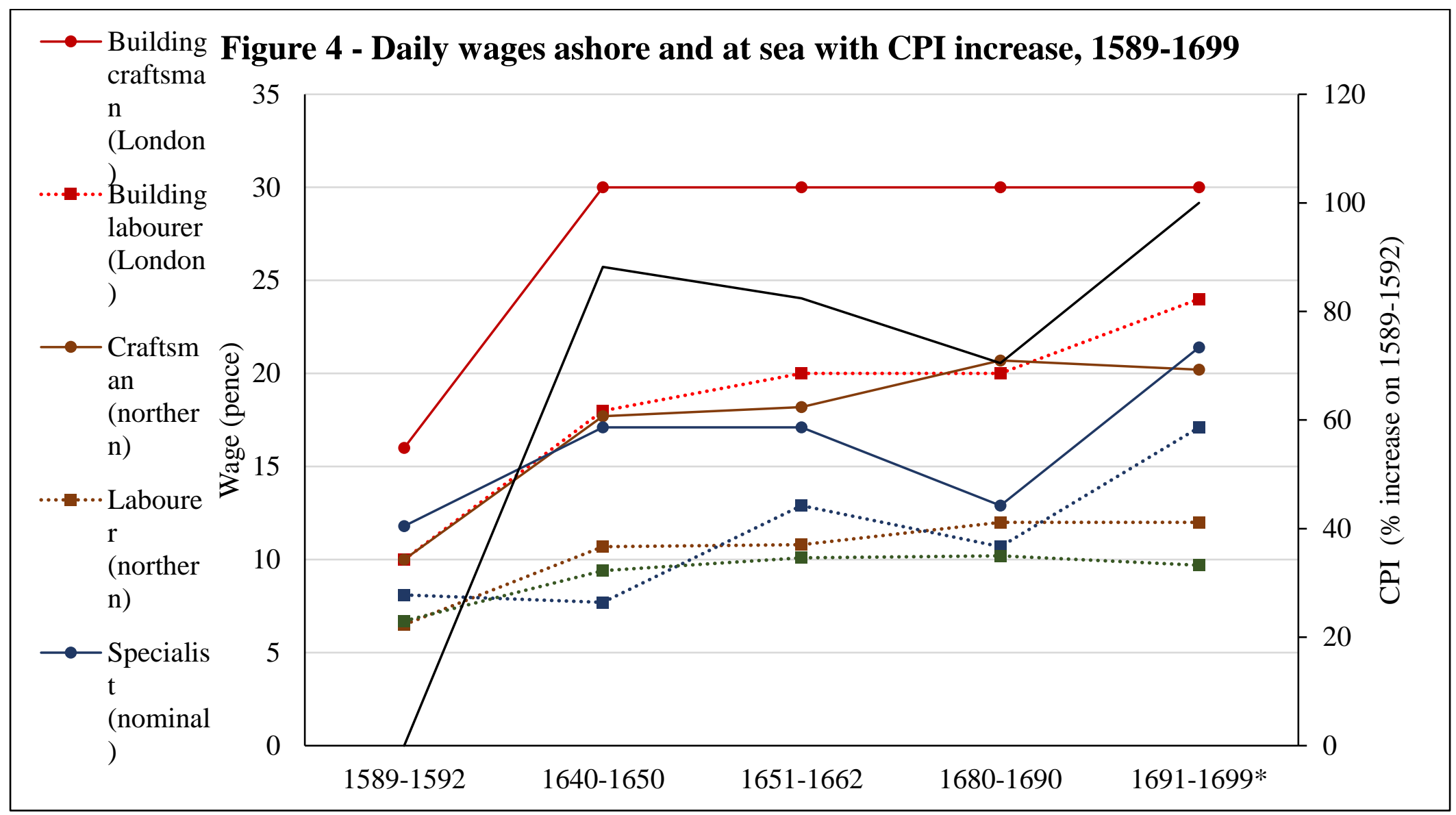

Sources: HCA wage dataset and Davis wage dataset(*) for mariner and specialist; Boulton, 'Wage labour', table 1 for London building labourer and craftsman; Allen, 'London', for northern labourer and craftsman and CPI, averaged across sample years; Clark, 'Long march', table 1, for farm labourer. Labels are used as presented in the sources. Modal wages for mariner and specialist have been used to match Boulton's figures, and have been converted, without adjustment for food, assuming a 28 -day month. 


\begin{tabular}{|c|c|c|c|c|c|}
\hline \multicolumn{6}{|c|}{ Table 9 - Seafarers' goods aboard ship, 1649-77 } \\
\hline \multicolumn{2}{|c|}{ The John Adventure, 1649} & \multicolumn{2}{|c|}{ The Eastland Merchant, 1657} & \multicolumn{2}{|c|}{ The Unity, 1677} \\
\hline Name (rank) & Goods & Name (rank) & Goods & Name (rank) & Goods \\
\hline Nathan Buskill * & $£ 14613 \mathrm{~s}$. & Lewes Cox * & $£ 8910$ s. & Jermeiah Johnson* & $£ 50$ \\
\hline Robert Eldred & $£ 1287 \mathrm{~s}$. & Charles Kearington & $£ 45$ & Daniel Dunn & $£ 40$ \\
\hline Isaack Jennings & $£ 100$ & Abraham Garratt & $£ 415 \mathrm{~s}$. & Athur Warringer & $£ 33$ \\
\hline Jasper Mott $\dagger$ & $£ 83$ 13s. & ? Michaell & $£ 4010$ s. & Daniel Pope & $£ 28$ \\
\hline Benjamin Strutt & $£ 76$ & George Kearington & $£ 3710$ s. & William Jones & $£ 17$ \\
\hline Warden White & $£ 55$ & Andrew Tod & $£ 3710$ s. & Vincent Dunn & $£ 17$ \\
\hline Julius Wood & $£ 50$ & Thomas Bradshaw & $£ 37$ & Zachariah Besill & $£ 9$ \\
\hline John Sayler $\dagger$ & $£ 50$ & Andrew Shan $\dagger$ & $£ 33$ 10s. & Richard Shepman & $£ 7$ \\
\hline Samuel \& Robert & & ? Dawling & $£ 33$ & 'nine other Seamen' & $£ 50$ \\
\hline Bromwell & $£ 4412 \mathrm{~s}$. & Samuell Lee & $£ 245 \mathrm{~s}$. & & \\
\hline Peter Couch & $£ 41$ & Robert Masters & $£ 215 \mathrm{~s}$. & & \\
\hline Thomas Davies & $£ 38$ & John Brooksy & $£ 215 \mathrm{~s}$. & & \\
\hline Francis Garland & $£ 30$ & ? Bondshaw & $£ 13$ 15s. & & \\
\hline George Hayward & $£ 30$ & Adam Hall & $£ 12$ 10s. & & \\
\hline George Dunninge & $£ 30$ & Marmaduke Walters & $£ 12$ 10s. & & \\
\hline Edward Hawkins $\dagger$ & $£ 29$ 19s. & Michaell Blewet & $£ 12$ 10s. & & \\
\hline Stephen North & $£ 20$ & Isaac Effer & $£ 915 \mathrm{~s}$. & & \\
\hline Henry Moore & $£ 15$ & Thomas Cooke & $£ 9$ 10s. & & \\
\hline John Hopkins & $£ 11$ & David Hutchines & $£ 710$ s. & & \\
\hline Martin Millard & $£ 8$ & James Bond & $£ 7$ & & \\
\hline Symon Williams & $40 \mathrm{~s}$. & ? Temple & $£ 65 \mathrm{~s}$. & & \\
\hline & & ? Hutton & $£ 65 \mathrm{~s}$. & & \\
\hline & & Christopher Russell & $£ 65 \mathrm{~s}$. & & \\
\hline & & ? Spencer & $£ 65 \mathrm{~s}$. & & \\
\hline & & Edward Hamond & $£ 65 \mathrm{~s}$. & & \\
\hline & & ? Johnson & $£ 5$ & & \\
\hline & & Robert Walterne & $£ 5$ & & \\
\hline & & Thomas Shakston & $£ 410$ s. & & \\
\hline & & ? Cryer & $£ 45 \mathrm{~s}$. & & \\
\hline & & John Cole & $£ 315 \mathrm{~s}$. & & \\
\hline & & ? Startt & $£ 35 \mathrm{~s}$. & & \\
\hline & & ? Hunter & $£ 2$ 10s. & & \\
\hline
\end{tabular}

* Master or master's mate $\dagger$ Specialist

Sources: John Adventure - TNA HCA 13/70, depositions of Samuel Bromwell and James Godden, 6 September 1654, fos 120r-1r, and Eustace Smith, 23 December 1654, fos 189r-v; HCA 13/71, deposition of Eustace Smith, 27 February 1654[/5], fo. 676r. Eastland Merchant - HCA 24/113/83; HCA 13/72, depositions of Andrew Shan, Peter Woollcock and John Cozens, 29 December 1657, Lewes Cox and Henry Dawling and Robert Masters, 31 December 1657, fos 203r-8r. Unity - HCA 24/121/187; HCA 1/79, depositions of Jeremy Johnson, Daniel Denn, John Parsons, Richard Shipman, and John Thorowgood, 18 September 1684. 